\title{
Changes in Aromatic Characteristics of Loureiro and Alvarinho Wines during Maturation
}

\author{
José M. Oliveira ${ }^{*}, 1$, Pedro Oliveira ${ }^{2}$, Raymond L. Baumes ${ }^{3}$, Odete Maia ${ }^{1}$ \\ ${ }^{1}$ IBB - Institute for Biotechnology and Bioengineering, Centre of Biological Engineering, Universidade do \\ Minho, Campus de Gualtar 4710-057, Braga, Portugal \\ ${ }^{2}$ Departamento de Produção e Sistemas, Universidade do Minho, Campus de Gualtar, 4710-057 Braga, Portugal \\ ${ }^{3}$ Unité Mixte de Recherches Sciences pour l'Enologie, INRA-M, 2, Place Viala, 36060 Montpellier Cedex 01, \\ France \\ * Corresponding author: Fax: +351 253 678986. Email: jmoliveira@deb.uminho.pt
}

\begin{abstract}
Changes in volatiles during maturation in bottles of monovarietal Vinhos Verdes wines from Loureiro and Alvarinho grape varieties, were followed by chemical and sensory analyses. Young wines and wines matured for 8 and 20 months were studied. The volatiles were determined by GC-MS after extraction on XAD-2 resin. Straight chain fatty acid ethyl esters and acetates of fusel alcohols decreased quicker for Loureiro wine, while the increase in ethyl esters of branched fatty acids was similar for both varieties. Linalool, Ho-trienol, $\alpha$-terpineol and $\beta$-damascenone could be used to differentiate between each variety. However, linalool decreased to negligible values after 20 months of maturation. $\beta$-damascenone decreased but remained high enough to be useful for differentiating each variety. Sensory analysis indicated a decrease of tropical fruit and tree fruit characters with conservation time for Alvarinho wine, and the opposite for Loureiro; moreover, citrus fruit character decreased in both varieties.
\end{abstract}

Keywords: wine; aroma; volatiles; Loureiro; Alvarinho; Vinhos Verdes; maturation conservation; ageing 


\section{Introduction}

Wines designated "Appellation of Origin Vinhos Verdes" are produced in Northern Portugal composed of 9 sub-regions (Amarante, Ave, Baião, Basto, Cávado, Lima, Monção, Paiva and Sousa). There are seven recommended white grape varieties (Alvarinho, Arinto, Avesso, Azal, Batoca, Loureiro and Trajadura) and eight red grape varieties (Amaral, Borraçal, Brancelho, Espadeiro, Padeiro de Basto, Pedral, Rabo de Ovelha and Vinhão) to produce these wines. Among the white cultivars, Alvarinho and Loureiro are employed to produce quality monovarietal wines, which are characterized by freshness and floral and fruity flavours. In order to preserve these characteristics, traditional winemaking techniques are developed to encourage these notes and to avoid malolactic fermentation. Legislation stipulates ethanol concentrations of between $8.0 \%$ and $11.5 \%$, but for Alvarinho wines it must be between $11.5 \%$ and $14.0 \%$; other monovarietal wines may have concentrations below $14.0 \%$. Fix acidity, expressed as tartaric acid, must be at least $4.5 \mathrm{~g} \mathrm{~L}^{-1}$. It is well known, however, that Vinhos Verdes loses quickly their aromatic characteristics during maturation. So, they are usually drunk during the first year; nevertheless, no systematic studies were conducted on this subject.

It is well known that during wine maturation and ageing there are many chemical changes in the volatile composition. These reactions depend on wine composition, $\mathrm{pH}$, storage time and temperature (Marais, 1978; Marais et al., 1980; Ramey et al., 1980; Usseglio-Tomasset, 1983). The majority of fatty acid ethyl esters is hydrolysed during conservation and, ethyl esters of fatty acids related to yeast nitrogen metabolism and esters of organic acids increase during this period (Díaz-Maroto et al., 2005; Dubois, 1994; Shinohara et al., 1981). Also, the terpenic profile may change, with the disappearance or strong decline of the compounds initially present, with the simultaneous formation of other terpenic compounds with higher oxidation state; temperature and $\mathrm{pH}$ have a decisive influence (Di Stefano, 1986 and 1989; Di 
Stefano and Castino, 1983; Marais et al., 1992). Some norisoprenoids may appear or increase their concentration during the ageing period, e. $g$. $\beta$-damascenone, TDN and vitispirane (Marais et al., 1992; Simpson, 1979; Simpson and Miller, 1983). The acidic medium also favours the hydrolysis of glycosidic precursors and the transformation of aglycon moieties (Dugelay, 1993; Günata et al., 1986; Sefton et al., 1993).

Since Loureiro and Alvarinho wines should be drunk as young wines (with about 8 months of conservation, in expert's opinion) and because their aromatic characteristics decline quickly during ageing, it is very important to study the volatile composition of these wines during storage in bottles. There are some published data on the volatile composition of Loureiro and Alvarinho wines (Guedes-de-Pinho, 1991; Oliveira, 1995; Oliveira et al., 1997; Rogerson and Silva, 1994) and the congeners Loureira and Albariño Galician wines of Northwest Spain (Falqué, 1998; García-Jares et al., 1994; Lema et al., 1996; Orriols and Camacho, 1991 and 1992; Orriols et al., 1993; Versini et al., 1994) but they do not refer to the changes occurring during maturation in the bottle. Nevertheless, Oliveira et al. (2008) conducted recently an exhaustive study on the volatile and glycosidically bound composition of Loureiro and Alvarinho wines.

The aim of the present work was to study the evolution of volatile composition of Loureiro and Alvarinho wines during maturation, i. e., at the end of alcoholic fermentation, and after stored in bottles, with 8 months and 20 months. Sensory evaluation was also undertaken for the last two stages.

\section{Materials and Methods}

\subsection{Grape samples}

About $40 \mathrm{~kg}$ of grapes were manually harvested in 1998, randomly, among the vines of 3 selected rows of the vineyard, at the recommended sub-region for each studied variety: Loureiro at Estação Vitivinícola Amândio Galhano -EVAG- (Lima sub-region), $\mathrm{L}_{\mathrm{AV}}$, and 
Alvarinho at Solar de Serrade (Monção sub-region), Ass. Both soils are from granitic origin and rows orientation is N-S. Loureiro and Alvarinho vineyards were 11 and 16 years old, respectively. Training systems and rootstocks are, respectively, for Loureiro and Alvarinho: single cordon and SO4; "cruzeta" and $1103 \mathrm{P}$.

\subsection{Vinifications}

Vinifications were made according to the traditional technology of the Vinhos Verdes region. The must obtained by crushing, pressing and static sedimentation was inoculated with Saccharomyces cerevisiae bayanus QA23. Fermentations took place at $18{ }^{\circ} \mathrm{C}$, in $10 \mathrm{~L}$ vessels, and were in duplicate. The produced wines were combined and the blend was treated with sodium bentonite -Volclay KWK Food Grade, 20-70 mesh, $10 \%$ in aqueous solution- (0.4 g

$\mathrm{L}^{-1}$ ), the $\mathrm{SO}_{2}$ content was corrected to $35 \mathrm{mg} \mathrm{L}^{-1}$, and submitted to cold stabilization (between $0{ }^{\circ} \mathrm{C}$ and $3{ }^{\circ} \mathrm{C}$ ) before bottling. The maturation of the wines occurred at cellar temperature and in the dark. The wines did not undergo malolactic fermentation. The evaluation of volatile composition was made in young wines $-\mathrm{W}_{1^{-}}$(subsequent to alcoholic fermentation), after 8 months $-\mathrm{W}_{2}-$ and 20 months $-\mathrm{W}_{3}$ - of maturation, which corresponds, respectively, to a period of 6 months and 18 months in bottle. General analyses of wines were performed at Comissão de Viticultura da Região dos Vinhos Verdes.

\subsection{Solvents}

All solvents were analytical grade and further purified. Diethyl ether (Merck, ref. 1.00921) was distilled on iron (II) sulphate (Merck, ref. 1.03965). Dichloromethane (Merck, ref. 1.06050) was washed with de-ionised water, and then distilled. Pentane (Carlo Erba, ref. 468151) was washed with $\mathrm{H}_{2} \mathrm{SO}_{4}$ (Merck, ref. 1.00731), $\mathrm{KMnO}_{4}$ (Carlo Erba, ref. 473387) and ultrapure water, and next it was distilled on potassium hydroxide (Merck, ref. 1.05033). Azeotrope pentane-dichloromethane was distilled after combination of pentane and dichloromethane $(2: 1, \mathrm{v} / \mathrm{v})$ and it was redistilled whenever necessary. 


\subsection{Extraction of volatile compounds}

Wine samples result from the content of three bottles, by blend, and were extracted in triplicate. To $100 \mathrm{~mL}$ of wine, centrifuged $\left(25 \mathrm{~min}, R C F=12225,4{ }^{\circ} \mathrm{C}\right)$ and diluted with ultrapure water to reduce the alcohol content to less than $5 \%$, were added $14.5 \mu \mathrm{g}$ of 4 nonanol (Merck, ref. 818773). The solution was passed through an Amberlite XAD-2 resin (20-60 mesh, Supelco, ref. 1-0357) column according to the method of Günata et al. (1985). Volatile compounds were eluted with $50 \mathrm{~mL}$ of azeotrope pentane-dichloromethane. The eluate was dried over anhydrous sodium sulphate and concentrated to about $2 \mathrm{~mL}$ by solvent evaporation at $34{ }^{\circ} \mathrm{C}$ through a Vigreux column, prior to analyses.

\subsection{Gas chromatography - mass spectrometry (GC-MS)}

Gas chromatographic analysis of volatile compounds was performed using a GC-MS (Varian 3400 Chromatograph and an ion-trap mass spectrometer Varian Saturn II). Each $1 \mu \mathrm{L}$ injection was made separately in two capillary columns, coated with CP-Wax 52 CB or CPWax $57 \mathrm{CB}(50 \mathrm{~m} \times 0.25 \mathrm{~mm}$ i.d., $0.2 \mu \mathrm{m}$ film thickness, Chrompack). The temperature of the injector (SPI - septum-equipped programmable temperature) was programmed from $20^{\circ} \mathrm{C}$ to $250{ }^{\circ} \mathrm{C}$, at $180{ }^{\circ} \mathrm{C} \min ^{-1}$. The temperature of the oven was held at $60{ }^{\circ} \mathrm{C}$, for $5 \mathrm{~min}$, then programmed from $60{ }^{\circ} \mathrm{C}$ to $250{ }^{\circ} \mathrm{C}\left(60{ }^{\circ} \mathrm{C}\right.$ to $220^{\circ} \mathrm{C}$ for the second column), at $3{ }^{\circ} \mathrm{C} \mathrm{min}^{-1}$, then held $20 \mathrm{~min}$ at $250{ }^{\circ} \mathrm{C}\left(30 \mathrm{~min}\right.$ at $\left.220{ }^{\circ} \mathrm{C}\right)$ and finally programmed from $250{ }^{\circ} \mathrm{C}$ to $255{ }^{\circ} \mathrm{C}$ at 1 ${ }^{\circ} \mathrm{C} \min ^{-1}\left(220{ }^{\circ} \mathrm{C}\right.$ to $225^{\circ} \mathrm{C}$ at $\left.2{ }^{\circ} \mathrm{C} \min ^{-1}\right)$. The carrier gas was helium N60 (Air Liquide), at $103 \mathrm{kPa}$. The detector was set to electronic impact mode $(70 \mathrm{eV})$, with an acquisition range $(\mathrm{m} / \mathrm{z})$ from 29 to 360 , and an acquisition frequency of $610 \mathrm{~ms}$.

\subsection{Identification and quantification of volatile compounds}

Identification was performed using the software Saturn version 5.2 (Varian), by comparing mass spectra and retention index with those of pure standard compounds. In some cases, the identification was achieved by comparing our retention index and mass spectra with 
published data. The quantification was performed using data obtained in CP-Wax $52 \mathrm{CB}$

column, mainly. The second column, CP-Wax $57 \mathrm{CB}$, served essentially to confirm spectra of the co-eluted compounds and, in general, it was useful for alcohols. All the compounds were determined, semi-quantitatively, as 4-nonanol equivalents.

\subsection{Sensory analysis}

Wines with 8 months $\left(\mathrm{W}_{2}\right)$ and 20 months $\left(\mathrm{W}_{3}\right)$ of maturation were submitted to sensory evaluation at Comissão de Viticultura da Região dos Vinhos Verdes (CVRVV). Judges were chosen amongst wine experts and they had a full knowledge about the products. $\mathrm{W}_{2}$ wines were evaluated by 7 tasters and $\mathrm{W}_{3}$ wines by 8 ( 5 of them being common to both); Loureiro and Alvarinho wines were coded randomly and tasted independently in each session using the distribution prepared according to aleatory tables. Normalised glasses were used (ISO 3591) and the room was kept at $21{ }^{\circ} \mathrm{C}$ and $65 \%$ of relative humidity. The wine score card was that used by Tasting Room of CVRVV, evaluating several attributes (scale 0 to 5) relating to visual, olfactory and gustative characteristics. Tasters also classified global appreciation (scale 0 to 20 ).

\subsection{Statistical analyses}

Statistical differences between wines, with respect to chemical analysis, were evaluated by Analysis of Variance (ANOVA) or, by independent-samples $\mathrm{T}$ test, when comparing wines from the two varieties with the same age. Homogeneity of variances was checked with the Levene test and normality of the variables was checked by the Kolgomorov-Smirnov test with Lilliefors correction, both at a significance level of $5 \%$. Whenever one of these two conditions fails, the non-parametric Kruskall-Wallis test was applied. Also, global classification obtained in the sensory analysis was studied by means of Analysis of Variance in order to evaluate hypothetical differences between wines of the same variety. ANOVA was also used to assess the evolution of wines between $\mathrm{W}_{2}$ and $\mathrm{W}_{3}$ respecting global appreciation. 
The behaviour of some compounds during conservation period was checked by Regression Analysis using linear, quadratic, cubic and exponential models, at a significance level of $5 \%$.

Similarities between wines, with respect to specific compounds, were analysed by Principal Component Analysis, being component extraction achieved by correlation matrix and their number fixed according to Kaiser criterion, i.e., all the components with eigenvalues over 1.

The software used was SPSS 14.0 for Windows.

\section{Results and Discussion}

\subsection{General analysis}

The various characteristics of the wines matured for 8 months are summarised in table 1 . Both monovarietal wines fulfil the criteria to obtain the Appellation of Origin Vinho Verde label.

\subsection{Volatile composition of Loureiro and Alvarinho wines}

The volatile extracts were obtained by solid phase extraction of diluted wines (lowering the alcoholic content below $5 \%$ ) using XAD-2 resin as report previously (Voirin et al., 1992; Aubert et al., 1997). GC-MS analysis allowed the identification and quantification of 120 volatile compounds including $5 \mathrm{C}_{6}$-compounds, 23 alcohols, 6 fatty acid ethyl esters related to lipid metabolism and 3 related to nitrogen metabolism, 10 esters of organic acids, 7 acetates,

8 monoterpenic alcohols, 15 monoterpenic oxides and diols, $13 \mathrm{C}_{13}$-norisoprenoids, 13 volatile phenols, 8 volatile fatty acids related to lipid metabolism and 3 related to nitrogen metabolism, 4 carbonyl compounds and also pantolactone and N-(2-phenylethyl)-acetamide (figure 1). This classification takes into account the chemical structure of the volatile compounds, the pathways that lead to their formation and the olfactory perception threshold. Only four compounds were identified by comparison of our retention index and mass spectra with published data and one was tentatively identified. 
Table 2 shows the mean level obtained for each compound in the nine samples analysed. These levels were determined, semi-quantitatively, as 4-nonanol equivalents.

Monoterpenic compounds (alcohols, oxides and diols), $\mathrm{C}_{13}$-norisoprenoids and some volatile phenols may be considered as varietal compounds because they were present in grape and/or arise from grape precursors. Unsaturated $\mathrm{C}_{6}$-alcohols are related to varietal origin because they can be formed, via $\mathrm{C}_{6}$-aldehydes, through enzymatic reactions from linolenic and linoleic acids present in grapes (Crouzet et al., 1998). However, because of their mainly fermentative origin, 1-hexanol, 4-ethylphenol, 4-vinylguaiacol and 4-vinylphenol were excluded from the varietal group (Chatonnet et al., 1992 and 1993; Joslin and Ough, 1978).

\subsection{Evolution of volatile compounds during bottle conservation}

Figure 2 represents the evolution of each group of volatile compounds during maturation of Loureiro and Alvarinho wines. Since the levels of esters of organic acids and volatile fatty acids related to yeast lipid metabolism are much higher than those of the other groups, they are not shown; furthermore, alcohols such as 2-methyl-1-butanol, 3-methyl-1-butanol and 2phenylethanol, are not included for the same reason. However, the change in their levels can be observed in table 2 .

The different groups of compounds generally behaved predictability. $\mathrm{C}_{6}$-compounds, alcohols and volatile fatty acids related to yeast lipid metabolism are almost stable during the 20 months of maturation. The small fluctuations observed in table 2 and figure 2 were not statistically significant $(p>0.05)$ except for $\mathrm{C}_{6}$-compounds in Alvarinho wine which demonstrated a slight decline $(F=6.228, p=0.034)$. Nevertheless, the analytical method used gave high concentration error for the more abundant alcohols (2-methyl-1-butanol, 3-methyl1-butanol and 2-phenylethanol), probably attributed to the mechanism of adsorption/desorption on XAD-2 resin and/or to column and/or detector saturation. Excluding these compounds, the sum of the other alcohols decrease for Alvarinho wine, chiefly between 
$\mathrm{W}_{1}$ and $\mathrm{W}_{2}$, whereas Loureiro wine present a minimum for the $\mathrm{W}_{2}$ stage $(p<0.05)$. However, benzyl alcohol increased significantly between $\mathrm{W}_{1}$ and $\mathrm{W}_{3}(p<0.05)$, predominantly for Alvarinho wine $(F=942.083, p=0.000)$, probably because of precursor hydrolysis.

The sum of 2-methyl-1-butanol and 3-methyl-1-butanol concentrations were near to their perception threshold limits of $7 \mathrm{mg} \mathrm{L}^{-1}$, contributing certainly to the olfactory characteristics of the 6 wines (Rapp and Mandery, 1986; Rapp and Versini, 1995; Salo, 1970). Also 3(methylthio)-1-propanol, with Odour Activity Values -OAV- (concentration/perception threshold) of approximately 0.1 , may contribute, although marginally, since its odour threshold is about $1 \mathrm{mg} \mathrm{L}^{-1}$ (Escudero et al., 2004; Meilgaard, 1975). On the other hand, 2phenylethanol may contribute decisively to the aroma of these wines, mainly Loureiro ones, as the concentration was at least twofold the perception threshold of $7.5 \mathrm{mg} \mathrm{L}^{-1}$ (Salo, 1970); nevertheless, the floral descriptor found by sensory analysis was not significantly related with its concentration, as it was expected from the rose-like aroma (Escudero et al., 2004; Meilgaard, 1975).

The $(E) /(Z)$ isomer ratio of 3-hexen-1-ol was almost constant during the storage period, with mean values of $6.33 \pm 0.22(n=9)$ and $0.66 \pm 0.02(n=9)$ for Loureiro and Alvarinho, respectively (95\% confidence level). These results indicate the possibility to discriminate wines from these two varieties.

The levels of esters of organic acids underwent a significant increase during the storage period, because of chemical esterification. This was most pronounced for monoethyl succinate, diethyl succinate and diethyl malate, in agreement with previous observations (Shinohara, 1984).

On the other hand, while the levels of acetates decreased sharply with ageing in the wines of both varieties, the ethyl esters of straight chain fatty acids related to yeast lipid metabolism decreased slowly and progressively during maturation of Loureiro wines, and did not 
significantly decreased in Alvarinho wines ( $p>0.05$ ). Thus, $\mathrm{W}_{3}$ Loureiro wine had $80 \%$ of the total level of the straight chain fatty acid ethyl esters present at the end of alcoholic fermentation $\left(\mathrm{W}_{1}\right)$ but it contained $5 \%$ only of acetates; $\mathrm{W}_{2}$ stage presented $97 \%$ and $30 \%$, respectively. In Alvarinho wines, acetates also decreased sharply from $\mathrm{W}_{1}$ to $\mathrm{W}_{2}$ and $\mathrm{W}_{3}$ stages, being about $52 \%$ and $11 \%$ respectively of the initial level, but this decrease was slower than in Loureiro wines. The faster ester hydrolysis in Loureiro wines could be due to their lower pH (Ramey and Ough, 1980). Contrarily to these esters, the ethyl esters of fatty acids related to yeast nitrogen metabolism, i. e. ethyl 2-methylbutyrate, ethyl 3methylbutyrate and ethyl benzeneacetate, increased in the wines of both varieties during the conservation period, as their esterification ratios were very low in $\mathrm{W}_{1}$ (Díaz-Maroto et al., 2005). The first two esters may contribute marginally to the aroma of Loureiro and Alvarinho wines as they present $O A V$ values above 0.1 , since their odour thresholds are $18 \mu \mathrm{g} \mathrm{L}^{-1}$ and 3 $\mu \mathrm{g} \mathrm{L}^{-1}$, respectively (Escudero et al., 2004); additionally, for $\mathrm{W}_{2}$ and $\mathrm{W}_{3}$ wines of both varieties, ethyl 3-methylbutyrate has $O A V$ values much higher than 1.0.

With the notable exception of linalool in Loureiro wines, the monoterpenic alcohols in the wines of both varieties had similar behaviours, showing a sharp increase between $\mathrm{W}_{1}$ and $\mathrm{W}_{2}$. As their levels were much lower than the levels of their bound forms (Oliveira et al., 2008), these variations were mainly due to the acid-catalyzed transformations of these monoterpenols during ageing, particularly that of linalool into $\alpha$-terpineol, linalool hydrate and furan linalool oxides, explaining its sharp decrease in Loureiro wines, but the hydrolysis of the bound forms could also be involved at a lesser extent, explaining the increase of linalool in Alvarinho wines (Di Stefano and Castino, 1983; Dugelay, 1993; Günata et al., 1986; Marais et al., 1992; Simpson and Miller, 1983; Usseglio-Tomasset and Di Stefano 1980; Williams et al., 1980 and 1982). Then, between $\mathrm{W}_{2}$ and $\mathrm{W}_{3}$, these effects continue, but due to the lowering of the levels of the starting materials of the above primary 
transformations, they were no longer able to match the decrease of the products formed, due to their own transformations into even more polar forms or more complex ones, leading to the beginning of their decrease.

Thus, monoterpenic alcohols present a maximum concentration in $\mathrm{W}_{2}$ wines for both varieties. The levels of linalool in Loureiro wine decreased almost linearly during the conservation period, being present in $\mathrm{W}_{3}$ only at trace amounts, whereas $\alpha$-terpineol and Hotrienol remained at these last stages the most abundant monoterpenols. It must be noted that after alcoholic fermentation $\left(\mathrm{W}_{1}\right)$, the level of linalool was approximately 3.5 times higher than in Alvarinho wine, but it decreased to the level in Alvarinho wine after 8 months of maturation $\left(\mathrm{W}_{2}\right)$, then kept on decreasing to very low levels for both varieties after 20 months of maturation $\left(\mathrm{W}_{3}\right)\left(2.0 \mu \mathrm{g} \mathrm{L}{ }^{-1}\right.$ and $12.0 \mu \mathrm{g} \mathrm{L}^{-1}$, respectively). On the other hand, the levels of Ho-trienol and $\alpha$-terpineol in the wines of both varieties became increasingly similar with ageing. Thus, ageing appeared to decrease differentiation of the wines of each variety based on these compounds. Myrcenol was characteristic of Loureiro wines, but it was not detected in grapes and musts of this variety (Oliveira, 2000; Oliveira et al., 2000).

The total levels of monoterpenic oxides and diols increased during the storage of the wines of both varieties. However, 2 groups of compounds could be differentiated. The first included furan linalool oxides, neroloxide and the hydrates of linalool, citronellol and terpin and demonstrated a sharp increase in their levels during the 20 months of maturation. The second group, included 3 oxides (pyran linalool oxides and exo-2-hydroxy-1,8-cineole) and the diendiols, did not present a significant evolution during the same period, but generally reached a maximum of concentration in the $\mathrm{W}_{2}$ wine. The behaviours of these 2 groups could be explained by the mechanisms detailed above for the monoterpenic alcohols. As reported previously (Oliveira et al., 2008), (Z)-8-hydroxylinalool may distinguish Alvarinho and Loureiro wines, increasing the difference with the storage time. 
For both varieties, the concentration of all the $\mathrm{C}_{13}$-norioprenoids increased during wine maturation, with the exception of $\beta$-damascenone and 3-hydroxy- $\beta$-damascone. These compounds constantly decreased, but $\beta$-damascenone was always present above its human perception threshold which is very low, $45 \mathrm{ng} \mathrm{L}^{-1}$ (Ribéreau-Gayon et al., 2000). Indeed, $\mathrm{C}_{13^{-}}$ norisoprenoids were found in musts and young wines almost exclusively as glycosidic precursors, with levels much higher than those of the free forms in the $\mathrm{W}_{1}$ wines. This explained their increase through hydrolysis of these bound forms during winemaking and the relatively short storage time of the study (Winterhalter, 1992 and 1996; Winterhalter and Schreier 1994). Thus, the $\mathrm{C}_{13}$-norisoprenoids listed in table 2 from 3-hydroxy-7,8-dihydro- $\beta$ ionone to vomifoliol were unchanged aglycons from these glycosides. On the other hand, the compounds listed from vitispirane I to 3-hydroxy- $\beta$-damascone arise from norisoprenoidic precursor transformations during wine conservation. The referred precursors of $\beta$ damascenone and 3-hydroxy- $\beta$-damascone are 3,6,9-trihydroxymegastigma-6,7-diene and 3hydroxy-7,8-dehydro- $\beta$-ionol (Puglisi et al., 2005; Winterhalter and Schreier, 1994); however, 3,6,9-trihydroxymegastigma-6,7-diene could not be identified under our GC-MS conditions. The sharp decrease of $\beta$-damascenone and 3-hydroxy- $\beta$-damascone, in contrast to the increase of other $\mathrm{C}_{13}$-norisoprenoids, would be explained by their rapid release from 3,6,9trihydroxymegastigma-6,7-diene and their interaction with sulfur dioxide, as demonstrated previously (Daniel et al., 2004). Indeed, $\beta$-damascenone and 3-hydroxy- $\beta$-damascone contained two reactive cross-conjugated enones moieties, absent in the ionone derivatives. On the other hand, TDN could derive from different precursors, namely 3 -hydroxy- $\beta$-ionone, $3,4-$ dihydroxy- $\beta$-ionol, 3,4-dihydroxy-7,8-dihydro- $\beta$-ionol, 3,9-dihydroxytheaspirane and 3,4dihydroxy-7,8-dihydro- $\alpha$-ionone, and as well as vitispiranes from 3,4-dihydroxy-7,8-dihydro$\beta$-ionol, megastigma-4-ene-3,6,9-triol and 3,4-dihydroxy-6,9-epoxymegastigmane 
(Winterhalter, 1993; Winterhalter and Skouroumounis, 1997; Winterhalter and Schreier, 1994; Winterhalter et al., 1998).

The most abundant volatile phenols, 4-vinylguaiacol and 4-vinylphenol, were mainly generated by yeasts during alcoholic fermentation, and decreased significantly during the storage time. That was consistent with their conversion during wine storage, into derivatives not amenable to our GC-MS conditions, such as 4-(ethoxyethyl)-phenol, 4-(ethoxyethyl)guaiacol and pyroanthocyanins (Dugelay et al., 1995; Hayasaka and Asenstorfer, 2002; Mateus et al., 2004). The other volatile phenols had a varietal origin, occurring mainly from hydrolysis of their glycoconjugates (Oliveira et al., 2000). As in the $\mathrm{W}_{1}$ wines, the levels of these bound forms were as low as those of their free forms (Oliveira et al., 2008). Variations were generally not significant, despite an upward trend.

Finally, volatile compounds supposed to influence the aromatic characteristics of Alvarinho and Loureiro wines (from their levels and perception thresholds) which exhibited statistically significant $(p<0.05)$ variations during bottle conservation were grouped according to their behaviour, i. e., if their level decreased, increased or if a maximum at $\mathrm{W}_{2}$ stage was observed (table 3). These results corroborate the discussion above as demonstrated in table 2 and figure 2. However, most variations observed in the wines of the two varieties were small, particularly those between the stages $\mathrm{W}_{2}$ and $\mathrm{W}_{3}$.

Overall results, concerning the total levels by groups of the varietal compounds in the 6 wines were analyzed by principal component analysis. Figure 3 represents the two first principal components, which accounted for $82.8 \%$ of samples initial variability. Component 1 accounted for $42.6 \%$ of total variance and showed the potential to discriminate between Loureiro and Alvarinho wines. Component 2, which explained 40.2 \%, allowed differentiation according to the ageing period. Loureiro wines were characterized by higher levels of $\mathrm{C}_{6}$-compounds and monoterpenic compounds, including alcohols, oxides and diols, 
whereas higher levels of varietal volatile phenols and $\mathrm{C}_{13}$-norisoprenoids were characteristic of $\mathrm{W}_{3}$ wines. On the other hand, the fermentative compounds listed in table 2 did not permit discrimination the wines of each cultivar, which was consistent with their usual classification as non-varietal compounds.

\subsection{Sensory analysis}

Sensorial descriptive analyses of Loureiro and Alvarinho wines with 8 months and 20 months of maturation were made (table 4).

Loureiro wines were clear. $\mathrm{W}_{2}$ wines revealed a pale citrus colour while $\mathrm{W}_{3}$ wine present a citrus colour, more appreciated by tasters. Wines were also classified as medium quality from overall sensations, including olfactory and gustative ones. Statistically, reporting on global appreciation, there were no differences between the two wines $(F=0.008, p>0.05)$, i.e., there was not any change of organoleptic characteristics. Alvarinho wines were clear and demonstrated an open straw colour. Concerning olfactory overall impression, the tasters considered that wines lost quality between $\mathrm{W}_{2}$ and $\mathrm{W}_{3}$ stages, having classified as "good" the wine after 8 months and as "medium" quality the wine after 20 months. This was caused by the lost of aromatic intensity on floral, citrus fruit and tropical fruit characters, and by the appearance of a slightly vegetal character. Gustative analysis revealed the same tendency. These considerations were also confirmed by statistic analysis considering global classification $(F=16.603, p<0.01)$.

Alvarinho variety are characterised by a more intense tropical fruit and tree fruit character (figure 4), while in Loureiro wines the floral and citrus fruit aromas are more pronounced. Alvarinho wines were also characterised by dried fruit flavour. These considerations are in agreement with Guedes-de-Pinho et al. (1998) and Cerdeira et al. (1998 and 1999).

The main aromatic descriptors for Alvarinho wine were tropical fruit, tree fruit and dried fruit whereas for Loureiro they were floral and citrus fruit. These descriptors may be 
associated to some flavour compounds; among them, (Z)-3-hexen-1-ol (green leaves), 3methylbutyl acetate (banana, apple), $\beta$-damascenone (tropical fruit, stewed apple), 4vinylguaiacol (phenolic, clove) and 4-vinylphenol (stramonium) may contribute chiefly for Alvarinho wines and 2-phenylethanol (rose), linalool (rose, floral, lemon) and Ho-trienol (linden) for Loureiro ones (Boidron et al., 1988; Escudero et al., 2004; Meilgaard, 1975; Ribéreau-Gayon et al., 2000).

During the maturation period (from 8 months to 20 months), Alvarinho wine lose overall aromatic intensity mainly related to tropical fruit, tree fruit and citrus fruit characters, while for Loureiro, only citrus fruit character decreased its intensity and the other two descriptors increased.

From the presented results it is clear that not all aroma sensations could be explained by the studied compounds. These monovarietal wines may contain some other aromatic contributors which were not identified by the methodology. In this context, varietal volatile thiols like 4methyl-4-mercaptopentan-2-one, 3-mercaptohexanol and 3-mercaptohexyl acetate were not considered because analytical methodology was not available, although they may have an important role.

Future work may consider a large number of analyses between initial and end points, i. $e$. between young wine and matured wine for several months. Maturation influence on flavor characteristics of wines may be only discussed on the basis of some key volatile compounds, which should be quantitatively determined.

\section{Acknowledgements}

The authors acknowledge the financial support provided by Centre of Biological Engineering of Universidade do Minho (CEB-UM). They also thank Estação Vitivinícola Amândio Galhano (EVAG) and Solar de Serrade for the grapes used in this study; and EVAG for the vinifications and Comissão de Viticultura da Região dos Vinhos Verdes for wine analyses. Russell Paterson is thanked for correcting English. 


\section{Literature Cited}

Aubert, C., Baumes, R.L., Günata, Y.Z., Lepoutre, J.P., Cooper, J.F., Bayonove, C.L., 1997. Effects of fluzilazole, a sterol siosynthesis inhibitor fungicide, on the free and bound aroma fraction of Muscat of Alexandria wines. J. Int. Sci. Vigne Vin 31, 57-64.

Boidron, J.-N., Chatonnet, P., Pons, M., 1988. Influence du bois sur certaines substances odorantes des vins. Conn. Vigne Vin 22, 275-294

Cerdeira, A.L., Cabral, M., Monteiro, F.F., 1998. Contribuição para a caracterização organoléptica de vinhos brancos de casta da Região Demarcada dos Vinhos Verdes. In $4^{\circ}$ Simpósio de Vitivinicultura do Alentejo pp. 105-111. Évora, Portugal.

Cerdeira, A.L., Cabral, M., Monteiro, F.F., 1999. Contribution for the sensorial characterization of three wine varieties Alvarinho, Loureiro and Pedernã from the Vinhos

Verdes Demarcated Region. In XXIV ${ }^{\text {ème }}$ Congrès Mondial de la Vigne et du Vin. $79^{\text {ème }}$ Assemblée Générale de l'OIV pp. 284-290. Mainz, Allemagne.

Chatonnet, P., Dubourdieu, D., Boidron, J.-N., Pons, M., 1992. The origin of ethylphenols in wines. J. Sci. Food Agric. 60, 165-178.

Chatonnet, P., Dubourdieu, D., Boidron, J.-N., Lavigne, V., 1993. Synthesis of volatile phenols by Saccharomyces cerevisiae in wines. J. Sci. Food Agric. 62, 191-202.

Crouzet, J., Flanzy, C., Günata, Y.Z., Pellerin, P., Sapis, J.C., 1998. Les enzymes en œnologie. In Enologie - Fondements Scientifiques et Technologiques Chap. nº 10, pp. 361411. Lavoisier Tec \& Doc, Paris.

Daniel, M.A., Elsey, G.M., Capone, D.L., Perkins, M.V., Sefton, M.A., 2004. Fate of damascenone in wine: the role of $\mathrm{SO}_{2}$. J. Agric. Food Chem. 52, 8127-8131

Di Stefano, R., 1986. Evoluzione dei composti responsabili dell'aroma di moscato durante la maturazione dell'uva, la fermentazione dei mosti e la conservazione dei vini. Atti Accad. Italiana Vite Vino 38, 233-244.

Di Stefano, R., 1989. Evoluzione dei composti terpenici liberi e glucosidici e degli actinidioli durante la conservazione dei mosti e dei vini in funzione del pH. Riv. Vitic. Enol. Conegliano 42, 11-23 
Di Stefano, R., Castino, M., 1983. Evoluzione dei composti di natura terpenica durante la conservazione dell'Asti spumante. Riv. Vitic. Enol. Conegliano 36, 245-258.

Díaz-Maroto, M., Schneider, R., Baumes, R., 2005. Formation pathways of ethyl esters of branched short-chain fatty acids during wine aging. J. Agric. Food Chem. 53, 3503-3509.

Dubois, P., 1994. Les arômes des vins et leurs défauts (cont.). Rev. Fr. Enol. 145, 27-40.

Dugelay, I., 1993. L'arôme du raisin: étude des précurseurs hétérosidiques et des activités enzymatiques exogènes impliquées dans leur hydrolyse. Applications technologiques. Ph. D. thesis, École Supérieure Agronomique de Montpellier, France.

Dugelay, I., Baumes, R.L., Günata, Y.Z., Razungles, A., Bayonove, C.L., 1995. Évolution de l'arôme au cours de la conservation du vin: formation de 4-(1-éthoxyéthyl)-phénol et 4-(1éthoxyéthyl)-gaïacol. Sci. Aliments 15, 423-433.

Escudero, A., Gogorza, B., Melus, M.A., Ortin, N., Cacho, J., Ferreira, V., 2004. Characterization of the aroma of a wine from Maccabeo. Key role played by compounds with low odor activity values. J. Agric. Food Chem. 52, 3516-3524.

Falqué, E., 1998. Caracterización de los aromas de cepas autóctonas de Galicia. Ph. D. thesis, Universidade de Vigo, Spain.

García-Jares, C., Carro-Mariño, N., Muñiz-Alonso, G., Cela-Torrijos, R., 1994. Research on the terpenic composition of galician musts and wines by GC-MS. In Proceedings of the Sixteenth International Symposium on Capillary Chromatography (P. Sandra, E.) pp. 602609. Riva del Garda, Italia.

Guedes-de-Pinho, P., 1991. Caractérisation de vins de la Région des Vinhos Verdes au Portugal. M. Sc. thesis, Institut d'Enologie, Université de Bordeaux II, France.

Guedes-de-Pinho, P., Santos, C., Vasconcelos, I., Silva, M.C., Hogg, T., Cabral, L., Vieira, M., Pessanha, M., Soares Franco, J.M., 1998. Defining the uniqueness of monovarietal wines from native portuguese varieties of Vitis vinifera. In $23^{\text {ème }}$ Congrès Mondial de la Vigne et du Vin pp. 83-88. Lisboa, Portugal. 
Günata, Y.Z., Bayonove, C.L., Baumes, R.L., Cordonnier, R.E., 1985. The aroma of grapes. I. Extraction and determination of free and glycosidically bound fractions of some aroma components. J. Chromatogr. 331, 83-90.

Günata, Y.Z., Bayonove, C.L., Baumes, R.L., Cordonnier, R.E., 1986. Stability of free and bound fractions of some aroma components of grapes cv. muscat during the wine processing: preliminary results. Am. J. Enol. Vitic. 37, 112-114.

Hayasaka, Y., Asenstorfer, E., 2002. Screening for potential pigments derived from anthocyanins in red wine using nanoelectrospray tandem mass spectroscopy. J. Agric. Food Chem. 50, 756-761.

Joslin, W., Ough, C., 1978. Cause and fate of certain $\mathrm{C}_{6}$ compounds formed enzymatically in macerated grape leaves during harvest and wine fermentation. Am. J. Enol. Vitic. 29, 1117.

Lema, C., García-Jares C., Orriols I., Angulo L., 1996. Contribution of Saccharomyces and non-Saccharomyces populations to the production of some components of Albariño wine aroma. Am. J. Enol. Vitic. 47, 206-216.

Marais, J., 1978. The effect of $\mathrm{pH}$ on esters and quality of Colombar wine during maturation. Vitis 17, 396-403.

Marais, J., Pool, H.J., 1980. Effect of storage time and temperature on the volatile composition and quality of dry white table wines. Vitis 19, 151-164.

Marais, J., van Wyk, C.J., Rapp, A., 1992. Effect of storage time, temperature and region on the levels of 1,1,6-trimethyl-1,2-dihydronaphtalene and other volatiles, and on quality of Weisser Riesling wines. S. Afr. J. Enol. Vitic. 13, 33-44.

Mateus, N., Oliveira, J., Haettich-Motta, M., Freitas, V., 2004 New family of bluish pyranoanthocyanins. Journal of Biomedicine and Biotechnology 5, 299-305.

Meilgaard, M.C., 1975. Flavor chemistry of beer: Part II: flavor and threshold of 239 aroma volatiles. MBAA Technical Quarterly 12, 151-168.

Oliveira, J.M., 1995. Influência da Tecnologia de Vinificação sobre a Qualidade Aromática de Vinhos da Casta Loureiro. M. Sc. thesis, Universidade do Minho, Braga, Portugal. 
Oliveira, J.M., 2000. Aromas varietais e de fermentação deteminantes da tipicidade das castas Loureiro e Alvarinho. Ph. D. thesis, Universidade do Minho, Braga, Portugal.

Oliveira, J.M., Sousa Maia, J., Maia, M.O., 1997. Application de bentonite aux moûts en fermentation: effet sur la formation et évolution du méthanol et des alcools supérieurs en deux cépages de la région des Vinhos Verdes, Loureiro et Trajadura. In XII ${ }^{\text {ème }}$ Congrés Mondial de la Vigne et du Vin; Buenos Aires, Argentina.

Oliveira, J.M., Maia M.O., Baumes, R.L., Bayonove, C.L., 2000. Free and bound aromatic components of Loureiro and Alvarinho grape varieties from the Vinhos Verdes region. Vitic. Enol. Sci. 55, 13-20.

Oliveira, J.M., Oliveira, P., Baumes, R.L., Maia, O., 2008. Volatile and glycosidically bound composition of Loureiro and Alvarinho wines. Food Sci. Technol. Int. 14 (in press).

Orriols, I., Camacho, F.M., 1991. Influencia de las levaduras en la formación de sustancias volátiles en la vinificación de la variedad Albariño. Vitivinicultura 2, 21-24.

Orriols, I., Camacho, F.M., 1992. Elaboración de vino Albariño. Incidencia de la maceración pelicular. Experiencias de 1989 e 1990. Vitivinicultura 3, 41-45.

Orriols, I., Alvarez, V., Perez, J., Rega, J., 1993. Les cépages blancs de Galice - Albariño, Loureira, Godello, Treixadura - et leurs composés volatils. In Connaissance Aromatique des Cépages et Qualité des Vins (C.L. Bayonove, J. Crouzet, C. Flanzy, C.A. Martin and J.C. Sapis, Eds.) pp. 166-171. Actes du Symposium International Montpellier; France.

Puglisi, C., Daniel, M., Capone, D., Elsey, G., Prager, R., Sefton, M., 2005. Precursors to damascenone: synthesis and hydrolysis of isomeric 3,9-dihydroxymegastigma-4,6,7-trienes. J. Agric. Food Chem. 53, 4895-4900.

Ramey, D.D., Ough, C.S., 1980. Volatile ester hydrolysis or formation during model solutions and wines. J. Agric. Food Chem. 28, 928-934.

Rapp, A., Mandery, H., 1986. Wine aroma. Experientia 42, 873-884.

Rapp, A., Versini, G., 1995. Influence of nitrogen compounds in grapes on aroma compounds of wines. In Food Flavors: Generation, Analysis and Process Influence (G. Charalambous, E.) pp. 1659-1694. $8^{\text {th }}$ International Flavor Conference, Cos, Greece; Elsevier. 
Ribéreau-Gayon, P., Glories, Y., Maujean, A., Dubourdieu, D., 2000. Varietal aroma. In Handbook of Enology (P. Ribéreau-Gayon, E.) Volume 2, pp. 187-206. John Wiley \& Sons.

Rogerson, F.S., Silva, M.C., 1994. Étude des monoterpenes libres et potentiels présents dans des vins issus de cépages blancs portugais. In I Congrès International de la Vitiviniculture Atlantique pp. 411-419. Pontevedra, España.

Salo, P., 1970. Determining the odor thresholds for some compounds in alcoholic beverages. J. Food Sci. 35, 95-99.

Sefton, M.A., Francis, I.L., Williams, P.J., 1993. The volatile composition of Chardonnay juices: A study by flavor precursor analysis. Am. J. Enol. Vitic. 44, 359-369.

Shinohara, T., 1984. L'importance des substances volatiles du vin. Formation et effets sur la qualité. Bull. OIV 641-642, 606-618.

Shinohara, T., Watanabe, M., 1981. Effects of fermentation conditions and aging temperature on volatile ester contents in wine. Agric. Biol. Chem. 45, 2645-2651.

Simpson R.F., 1979. Aroma composition of bottle aged wine. Vitis 18, 148-154.

Simpson, R.F., Miller, G.C., 1983. Aroma composition of aged Riesling wine. Vitis 22, 5163.

Usseglio-Tomasset, L., 1983. Influence de la temperature de conservation sur les caractéristiques physico-chimiques et organoleptiques des vins (vins aromatiques). Bull. OIV 623, 19-34.

Usseglio-Tomasset, L., Di Stefano, R., 1980. Profilo aromatico del Moscato bianco del Piemonte. Riv. Vitic. Enol. Conegliano 33, 55-68.

Versini, G., Orriols, I., Dalla Serra, A., 1994. Aroma components of Galician Albariño, Loureira and Godello wines. Vitis 33, 165-170.

Voirin, S., Baumes, R.L., Sapis, J.C., Bayonove C.L., 1992. Analytical methods for monoterpene glycosides in grape and wine. II. Qualitative and quantitative determination of monoterpene glycosides in grape. J. Chromatogr. 595, 269-281. 
Williams, P.J., Strauss, C.R., Wilson, B., 1980. Hydroxylated linalool derivatives as precursors of volatile monoterpenes of muscat grapes. J. Agric. Food Chem. 28, 766-771.

Williams, P.J., Strauss, C.R., Wilson, B., Massy-Westropp, R.A., 1982. Studies on the hydrolysis of Vitis vinifera monoterpene precursor compounds and model monoterpene- $\beta-\mathrm{D}-$ glucosides rationalizing the monoterpene composition of grapes. J. Agric. Food Chem. 30, 1219-1223.

Winterhalter P., 1992. Oxygenated $\mathrm{C}_{13}$-norisoprenoids: important flavor precursors. In Flavor Precursors: Thermal and Enzymatic Conversions (R. Teranishi, G.R. Takeoka and M. Guntert, Eds.) pp. 98-115. ACS Symposium Series 490, Am. Chem. Soc., Washington DC.

Winterhalter P., 1993. The generation of $\mathrm{C}_{13}$-norisoprenoid volatiles in Riesling wine. In Connaissance Aaromatique des Cépages et Qualité des Vins (C.L. Bayonove, J. Crouzet, C. Flanzy, C.A. Martin and J.C. Sapis, Eds.) pp. 65-73. Actes du Symposium International Montpellier.

Winterhalter, P., 1996. Carotenoid-derived aroma compounds: biogenetic and biotechnological aspects. In Biotechnology for Improved Foods and Flavors (G.R. Takeoka, R. Teranishi, P.J. Williams and A. Kobayashi, Eds.) pp. 295-308. ACS Symposium Series 637, Am. Chem. Soc.

Winterhalter, P., Schreier, P., 1994. $C_{13}$-norisoprenoid glycosides in plant tissues: an overview on their occurrence, composition and role as flavour precursors. Flavour Fragr. J. 9, 281-287.

Winterhalter, P., Skouroumounis, G.K., 1997. Glycoconjugated aroma compounds: occurence, role and biotechnological transformation. In Advances in Biochemical Engineering/Biotechnology (R.G. Berger, E.) vol. 55 - Biotechnology of Aromas, pp. 73-105. Springer Verlag, Heidelberg, Germany.

Winterhalter, P., Baderschneider, B., Bonnländer, B., 1998. Analysis, structure, and reactivity of labile terpenoid aroma precursors in Riesling wine. In Chemistry of Wine Flavor (S. Ebeler and A. Waterhouse, Eds.) pp. 1-12. ACS Symposium Series 714, Am. Chem. Soc., Washington, USA. 
Table 1. General analysis of wines with 8 months $\left(\mathrm{L}_{\mathrm{Av}}-\mathrm{W}_{2}\right.$ and $\left.\mathrm{A}_{\mathrm{SS}}-\mathrm{W}_{2}\right)$

\begin{tabular}{lcc}
\cline { 2 - 3 } & Loureiro & Alvarinho \\
\hline Ethanol/(\% vol. $)$ & 10.2 & 13.5 \\
Reducing sugars/ $\left(\mathrm{g} \mathrm{L}^{-1}\right)$ & 1.1 & 3.4 \\
Total acidity ${ }^{*} /\left(\mathrm{g} \mathrm{L}^{-1}\right)$ & 10.6 & 7.6 \\
Volatile acidity ${ }^{* *} /\left(\mathrm{g} \mathrm{L}^{-1}\right)$ & 0.33 & 0.40 \\
$\mathrm{pH}$ & 2.81 & 3.03 \\
\hline
\end{tabular}

, as tartaric acid

** as acetic acid 
Table 2. Mean levels ${ }^{*}(C)$ with $95 \%$ confidence limits for the volatile compounds found in Loureiro $\left(\mathrm{L}_{\mathrm{AV}}\right)$ and Alvarinho $\left(\mathrm{A}_{\mathrm{SS}}\right)$ wines, after alcoholic fermentation $\left(\mathrm{W}_{1}\right)$ and after 8 months $\left(\mathrm{W}_{2}\right)$ and 20 months $\left(\mathrm{W}_{3}\right)$ of maturation

\begin{tabular}{|c|c|c|c|c|c|c|c|c|c|c|c|c|c|c|c|}
\hline & \multirow{4}{*}{ \# } & \multirow{4}{*}{ roi } & \multirow{4}{*}{$\boldsymbol{R I}$} & & & & & & & & & & & & \\
\hline & & & & \multicolumn{6}{|c|}{ Loureiro } & \multicolumn{6}{|c|}{ Alvarinho } \\
\hline & & & & \multicolumn{2}{|l|}{$\mathbf{W}_{1}$} & \multicolumn{2}{|l|}{$\mathbf{W}_{2}$} & \multicolumn{2}{|l|}{$\mathbf{W}_{3}$} & \multicolumn{2}{|l|}{$\mathbf{W}_{1}$} & \multicolumn{2}{|l|}{$\mathbf{W}_{2}$} & \multicolumn{2}{|l|}{$\mathbf{W}_{3}$} \\
\hline & & & & $C /(\mu \mathrm{g} \mathrm{L}-1)$ & \pm & $C /\left(\mu \mathrm{g} \mathrm{L}^{-1}\right)$ & \pm & $C /\left(\mu \mathrm{g} \mathrm{L}^{-1}\right)$ & \pm & $C /(\mu \mathrm{g} \mathrm{L}-1)$ & \pm & $C /(\mu \mathrm{g} \mathrm{L}-1)$ & \pm & $C /\left(\mu \mathrm{g} \mathrm{L}^{-1}\right)$ & \pm \\
\hline \multicolumn{16}{|l|}{$\mathrm{C}_{6}$-compounds(5) } \\
\hline 1-hexanol & 1 & $a$ & 1348 & 972.2 & 145.9 & 976.8 & 109.4 & 1195.6 & 689.5 & 869.5 & 137.1 & 739.5 & 152.0 & 765.5 & 91.7 \\
\hline (E)-3-hexen-1-ol & 2 & $a$ & 1358 & 206.2 & 56.9 & 182.7 & 11.6 & 233.0 & 139.9 & 57.6 & 11.9 & 46.6 & 4.9 & 49.8 & 9.3 \\
\hline (Z)-3-hexen-1-ol & 3 & $a$ & 1379 & 33.6 & 11.3 & 29.6 & 3.9 & 35.0 & 22.4 & 90.4 & 17.8 & 71.3 & 4.8 & 72.7 & 10.7 \\
\hline (E)-2-hexen-1-ol & 4 & $a$ & 1400 & $\operatorname{tr}$ & & 0.2 & 0.7 & $\operatorname{tr}$ & & - & & $\operatorname{tr}$ & & 0.2 & 0.2 \\
\hline (Z)-2-hexen-1-ol & 5 & $a$ & 1410 & 2.3 & 0.8 & 2.0 & 0.5 & 2.4 & 1.4 & 0.9 & 0.2 & 0.8 & 0.1 & 0.7 & 0.2 \\
\hline total & & & & 1214.3 & & 1191.3 & & 1466.0 & & 1018.4 & & 858.2 & & 888.9 & \\
\hline \multicolumn{16}{|l|}{ Alcohols (23) } \\
\hline 2-methyl-3-buten-2-ol & 6 & $a$ & 1068 & 2.6 & 0.0 & 6.7 & 2.8 & 7.8 & 2.7 & $?$ & & 3.7 & 0.9 & 2.8 & 0.7 \\
\hline 2-methyl-1-propanol & 7 & $a$ & 1082 & 1233.1 & 535.3 & 775.1 & 100.2 & 932.7 & 689.9 & 1435.0 & 141.1 & 1067.2 & 344.2 & 986.6 & 143.8 \\
\hline 1-butanol & 8 & $a$ & 1140 & 22.7 & 14.0 & 18.3 & 1.8 & 20.9 & 13.7 & 68.6 & 9.5 & 50.0 & 15.0 & 47.2 & 7.0 \\
\hline 4-methyl-2-pentanol & 9 & $a$ & 1164 & 45.5 & 18.6 & 41.6 & 10.6 & 55.6 & 31.6 & 53.9 & 15.3 & 52.4 & 11.7 & 49.8 & 3.3 \\
\hline $\begin{array}{l}\text { 2-methyl-1-butanol } \\
\quad+3 \text {-methyl-1-butanol }\end{array}$ & $\begin{array}{l}10 \\
11\end{array}$ & $a$ & 1204 & 58535.5 & 28686.6 & 54741.1 & 12317.2 & 64583.2 & 3058.8 & 74488.5 & 25717.8 & 71637.3 & 29248.7 & 65672.3 & 23675.9 \\
\hline 3-methyl-3-buten-1-ol & 12 & $a$ & 1243 & 4.3 & 1.9 & 3.6 & 0.9 & 2.4 & 1.1 & 5.5 & 0.9 & 4.1 & 1.6 & 3.5 & 1.1 \\
\hline 1-pentanol & 13 & $a$ & 1244 & 6.5 & 3.2 & 6.5 & 2.9 & 13.4 & 16.7 & 11.6 & 2.7 & 10.0 & 4.5 & 10.7 & 1.8 \\
\hline 2-methyl-1-pentanol & 14 & $a$ & 1298 & $?$ & & 0.6 & 0.1 & 0.3 & 0.6 & - & & - & & - & \\
\hline 4-methyl-1-pentanol & 15 & $a$ & 1309 & 26.8 & 6.8 & 24.3 & 3.7 & 29.6 & 14.6 & 37.5 & 6.5 & 32.5 & 4.9 & 32.2 & 3.5 \\
\hline (Z)-2-penten-1-ol & 16 & $a$ & 1313 & 0.7 & 0.3 & 0.3 & 0.1 & 0.4 & 0.3 & 0.7 & 1.4 & 0.4 & 0.3 & 0.6 & 0.1 \\
\hline $\begin{array}{l}\text { 3-methyl-2-buten-1-ol } \\
+2 \text {-heptanol }\end{array}$ & $\begin{array}{l}17 \\
18\end{array}$ & $\begin{array}{l}a \\
a\end{array}$ & 1316 & 2.5 & 0.9 & 2.8 & 0.7 & 3.8 & 2.9 & 2.3 & 1.4 & 1.3 & 0.3 & 1.3 & 0.5 \\
\hline 3-methyl-1-pentanol & 19 & $a$ & 1322 & 65.5 & 16.5 & 54.5 & 29.1 & 75.1 & 38.8 & 140.3 & 32.7 & 113.7 & 8.7 & 118.6 & 19.3 \\
\hline 3-ethoxy-1-propanol & 20 & $a$ & 1369 & 66.5 & 41.6 & 58.2 & 7.4 & 56.8 & 41.7 & 75.5 & 16.6 & 54.2 & 11.5 & 48.6 & 6.1 \\
\hline 1-octen-3-ol & 21 & $a$ & 1445 & 1.1 & 0.1 & 1.0 & 0.4 & 1.1 & 0.3 & 0.7 & 0.4 & 0.6 & 0.3 & 0.7 & 0.2 \\
\hline 1-heptanol & 22 & $a$ & 1449 & 16.4 & 3.3 & 14.7 & 0.9 & 16.6 & 3.4 & 13.7 & 2.4 & 12.3 & 2.8 & 12.0 & 0.3 \\
\hline 2-nonanol & 23 & $a$ & 1541 & 1.0 & 1.3 & 1.0 & 0.3 & 1.1 & 2.7 & 1.5 & 0.7 & 2.7 & 5.1 & 1.5 & 1.1 \\
\hline 1-octanol & 24 & $a$ & 1552 & 9.5 & 0.6 & 13.5 & 3.1 & 10.8 & 2.0 & 6.2 & 1.6 & 8.3 & 0.6 & 7.7 & 1.2 \\
\hline 3-(methylthio)-1-propanol & 25 & $a$ & 1709 & 103.4 & 67.2 & 79.8 & 11.8 & 84.5 & 55.5 & 135.2 & 25.3 & 98.5 & 20.6 & 87.1 & 8.3 \\
\hline benzyl alcohol & 26 & $a$ & 1869 & 5.2 & 1.2 & 18.2 & 8.3 & 16.2 & 9.6 & 5.9 & 1.2 & 13.7 & 1.8 & 36.4 & 3.2 \\
\hline 2-phenylethanol & 27 & $a$ & 1908 & 28196.3 & 21202.6 & 23561.6 & 3908.8 & 31281.4 & 14343.7 & 20507.9 & 4319.5 & 15894.8 & 6174.5 & 16464.7 & 8149.2 \\
\hline tyrosol & 28 & $a$ & 3008 & 127.1 & 65.8 & 152.1 & 30.8 & 222.6 & 157.7 & 61.7 & 25.4 & 123.0 & 30.0 & 142.9 & 31.9 \\
\hline total & & & & 88472.2 & & 79575.5 & & 97416.3 & & 97052.2 & & 89180.7 & & 83727.2 & \\
\hline $\operatorname{totaI}^{* *}$ & & & & 1740.4 & & 1272.8 & & 1551.7 & & 2055.8 & & 1648.6 & & 1590.2 & \\
\hline \multicolumn{16}{|l|}{$\begin{array}{l}\text { Fatty acid ethyl esters - lipid } \\
\text { metabolism (6) }\end{array}$} \\
\hline ethyl butyrate & 29 & $a$ & 1032 & 167.7 & 15.9 & 141.7 & 4.7 & 146.3 & 55.3 & 221.4 & 19.4 & 211.2 & 28.6 & 196.2 & 14.9 \\
\hline ethyl hexanoate & 30 & $a$ & 1234 & 465.1 & 46.0 & 422.8 & 51.1 & 336.7 & 44.1 & 513.6 & 75.5 & 488.5 & 46.4 & 462.5 & 49.1 \\
\hline ethyl octanoate & 31 & $a$ & 1434 & 482.1 & 30.3 & 545.5 & 48.3 & 437.1 & 153.5 & 577.8 & 91.0 & 672.7 & 170.3 & 664.2 & 71.2 \\
\hline ethyl decanoate & 32 & $a$ & 1636 & 151.0 & 25.3 & 107.1 & 16.8 & 76.4 & 38.1 & 169.9 & 17.9 & 240.1 & 104.9 & 171.2 & 10.4 \\
\hline ethyl 9-decenoate & 33 & $b, c$ & 1688 & 55.6 & 11.4 & 52.7 & 8.5 & 36.1 & 18.2 & 42.9 & 6.0 & 67.5 & 28.2 & 48.5 & 5.7 \\
\hline ethyl dodecanoate & 34 & $a$ & 1855 & 7.1 & 3.3 & 3.8 & 1.8 & $?$ & & 9.7 & 1.0 & 6.3 & 4.6 & 5.7 & 1.6 \\
\hline total & & & & 1328.6 & & 1273.6 & & 1032.6 & & 1535.3 & & 1686.3 & & 1548.3 & \\
\hline \multicolumn{16}{|c|}{$\begin{array}{l}\text { Fatty acid ethyl esters - nitrogen } \\
\text { metabolism (3) }\end{array}$} \\
\hline ethyl 2-methylbutyrate & 35 & $a$ & 1049 & - & & 3.2 & 1.4 & 8.8 & 1.4 & tr & & 5.1 & 2.5 & 12.9 & 0.9 \\
\hline ethyl 3-methylbutyrate & 36 & $a$ & 1066 & 2.4 & 0.3 & 8.5 & 2.2 & 22.2 & 1.1 & 1.8 & 0.5 & 11.3 & 0.8 & 28.2 & 1.5 \\
\hline ethyl benzeneacetate & 37 & $a$ & 1782 & 1.3 & 0.4 & 2.0 & 0.6 & 4.0 & 1.3 & 0.5 & 0.4 & 2.8 & 0.8 & 5.9 & 0.1 \\
\hline total & & & & 3.7 & & 13.7 & & 35.0 & & 2.3 & & 19.2 & & 47.0 & \\
\hline
\end{tabular}




\begin{tabular}{|c|c|c|c|c|c|c|c|c|c|c|c|c|c|c|c|}
\hline \multicolumn{16}{|l|}{ Esters of organic acids (10) } \\
\hline ethyl pyruvate & 38 & $a$ & 1267 & - & & 7.1 & 1.6 & 37.9 & 30.1 & - & & 9.6 & 0.0 & 39.6 & 4.9 \\
\hline ethyl lactate & 39 & $a$ & 1338 & 266.3 & 145.9 & 472.3 & 103.5 & 463.8 & 246.8 & 188.4 & 33.8 & 437.7 & 72.9 & 478.6 & 73.0 \\
\hline ethyl 3-hydroxybutyrate & 40 & $a$ & 1512 & 40.3 & 22.7 & 36.2 & 4.2 & 43.1 & 28.7 & 77.1 & 14.7 & 58.4 & 7.9 & 59.3 & 5.7 \\
\hline diethyl malonate & 41 & $a$ & 1574 & - & & 1.7 & 0.2 & 5.3 & 1.9 & $\operatorname{tr}$ & & 3.1 & 0.2 & 11.6 & 0.8 \\
\hline ethyl 2-furoate & 42 & $a$ & 1618 & 0.4 & 0.3 & 2.2 & 0.5 & 6.7 & 2.2 & 1.6 & 1.3 & 4.4 & 1.3 & 11.9 & 0.4 \\
\hline diethyl succinate & 43 & $a$ & 1672 & 41.0 & 5.6 & 896.4 & 7.1 & 3760.0 & 1227.6 & 27.5 & 9.1 & 966.3 & 101.5 & 4569.4 & 426.1 \\
\hline diethyl glutarate & 44 & $a$ & 1774 & 0.5 & 0.2 & 6.2 & 0.2 & 13.1 & 1.4 & $\operatorname{tr}$ & & 8.2 & 1.1 & 24.5 & 0.6 \\
\hline diethyl malate & 45 & $a$ & 2037 & 164.7 & 52.6 & 2477.7 & 292.6 & 11363.6 & 5670.8 & 39.1 & 13.0 & 1248.8 & 108.7 & 6162.3 & 479.2 \\
\hline diethyl tartrate & 46 & $a$ & 2351 & - & & 43.2 & 10.4 & 590.3 & 1537.0 & - & & 10.6 & 5.2 & 186.8 & 16.3 \\
\hline monoethyl succinate & 47 & $a$ & 2377 & 452.8 & 131.7 & 3473.8 & 525.2 & 8905.7 & 7612.2 & 105.8 & 81.4 & 3305.1 & 604.4 & 8940.2 & 1321.3 \\
\hline total & & & & 966.0 & & 7416.8 & & 25189.5 & & 439.5 & & 6052.2 & & 20484.2 & \\
\hline \multicolumn{16}{|l|}{ Acetates (7) } \\
\hline 2-methylpropyl acetate & 48 & $a$ & 1009 & 32.0 & 17.5 & 11.3 & 6.6 & 2.6 & 1.8 & 40.8 & 13.3 & 16.9 & 12.0 & 4.2 & 3.1 \\
\hline butyl acetate & 49 & $a$ & 1071 & 2.3 & 0.5 & $\operatorname{tr}$ & & - & & 3.0 & 1.3 & 1.5 & 1.0 & - & \\
\hline 3-methylbutyl acetate & 50 & $a$ & 1125 & 1041.4 & 89.3 & 331.3 & 16.4 & 63.5 & 4.6 & 1567.5 & 150.2 & 823.5 & 36.8 & 168.4 & 4.1 \\
\hline hexyl acetate & 51 & $a$ & 1272 & 181.4 & 7.3 & 47.1 & 1.4 & 2.4 & 1.9 & 151.5 & 13.9 & 64.5 & 8.8 & 8.6 & 1.3 \\
\hline$(Z)$-3-hexenyl acetate & 52 & $a$ & 1307 & 8.9 & 0.8 & 2.7 & 0.7 & - & & 3.0 & 0.5 & 1.3 & 0.2 & $\operatorname{tr}$ & \\
\hline 2-phenylethyl acetate & 53 & $a$ & 1810 & 249.9 & 7.8 & 93.2 & 8.5 & 16.1 & 0.3 & 325.1 & 7.7 & 189.4 & 10.1 & 41.8 & 2.6 \\
\hline tryptophyl acetate & 54 & $b, c$ & 3369 & 75.1 & 8.0 & 6.1 & 1.4 & - & & 20.5 & 2.0 & 3.9 & 1.7 & 0.3 & 0.1 \\
\hline total & & & & 1591.0 & & 491.7 & & 84.6 & & 2111.4 & & 1101.0 & & 223.3 & \\
\hline \multicolumn{16}{|l|}{ Monoterpenic alcohols (8) } \\
\hline myrcenol & 55 & $a$ & 1533 & 3.9 & 2.1 & 8.0 & 5.6 & 17.9 & 1.9 & - & & - & & - & \\
\hline linalool & 56 & $a$ & 1541 & 143.2 & 11.6 & 68.6 & 5.3 & 2.0 & 0.8 & 39.9 & 3.7 & 78.4 & 5.5 & 12.0 & 1.5 \\
\hline 4-terpineol & 57 & $a$ & 1597 & 1.0 & 0.4 & 1.0 & 0.1 & 1.4 & 0.5 & 0.9 & 0.2 & 0.8 & 0.4 & 0.9 & 0.6 \\
\hline Ho-trienol & 58 & $a$ & 1605 & 31.0 & 8.0 & 102.0 & 24.7 & 80.2 & 43.7 & 25.5 & 2.3 & 60.8 & 15.9 & 54.0 & 4.0 \\
\hline$\alpha$-terpineol & 59 & $a$ & 1691 & 21.2 & 3.7 & 111.6 & 11.5 & 66.0 & 18.3 & 11.8 & 2.1 & 67.8 & 8.3 & 72.7 & 8.9 \\
\hline citronellol & 60 & $a$ & 1760 & 7.2 & 1.7 & 2.6 & 0.4 & $\mathrm{tr}$ & & 7.3 & 1.4 & 4.0 & 0.8 & 0.7 & 0.2 \\
\hline nerol & 61 & $a$ & 1793 & 2.6 & 1.4 & 3.1 & 1.3 & $\operatorname{tr}$ & & 1.2 & 0.4 & 5.7 & 2.1 & $?$ & \\
\hline geraniol & 62 & $a$ & 1847 & 3.2 & 1.8 & $?$ & & $?$ & & 8.3 & 1.8 & $?$ & & 3.3 & 0.5 \\
\hline total & & & & 213.3 & & 269.9 & & 167.5 & & 94.9 & & 217.5 & & 143.6 & \\
\hline \multicolumn{16}{|l|}{ Monoterpenic oxides and diols (15) } \\
\hline trans- furan linalool oxide & 63 & $a$ & 1436 & 13.7 & 2.4 & 29.1 & 3.3 & 81.6 & 18.4 & 1.2 & 0.5 & 13.6 & 5.8 & 36.8 & 4.7 \\
\hline cis- furan linalool oxide & 64 & $a$ & 1464 & 3.2 & 0.9 & 11.5 & 0.1 & 33.1 & 9.6 & 0.6 & 0.0 & 3.6 & 0.9 & 12.7 & 1.4 \\
\hline neroloxide & 65 & $b, c$ & 1467 & 9.1 & 2.7 & 16.3 & 0.6 & 38.0 & 9.9 & 6.5 & 0.8 & 11.6 & 1.7 & 26.8 & 0.3 \\
\hline trans- pyran linalool oxide & 66 & $a$ & 1732 & 92.5 & 29.0 & 73.3 & 7.8 & 93.3 & 48.9 & 7.0 & 3.5 & 7.0 & 1.1 & 12.2 & 2.1 \\
\hline$c i s$ - pyran linalool oxide & 67 & $a$ & 1756 & 16.6 & 3.2 & 17.9 & 2.8 & 15.6 & 9.7 & $\operatorname{tr}$ & & 0.5 & 0.2 & $\operatorname{tr}$ & \\
\hline exo-2-hydroxy-1,8-cineole & 68 & $a$ & 1857 & 2.0 & 0.9 & 0.9 & 0.5 & 2.1 & 2.2 & - & & - & & - & \\
\hline 3,7-dimethylocta-1,5-dien-3,7-diol & 69 & $a$ & 1935 & 223.4 & 48.4 & 297.7 & 32.4 & 210.1 & 135.1 & 64.9 & 31.7 & 217.1 & 17.3 & 189.7 & 32.0 \\
\hline linalool hydrate & 70 & $a$ & 1967 & 3.0 & 1.6 & 47.6 & 5.3 & 63.9 & 21.7 & 0.6 & 1.0 & 15.1 & 5.9 & 41.7 & 0.9 \\
\hline terpin hydrate & 71 & $a$ & 2087 & - & & 11.0 & 3.5 & 53.6 & 41.8 & - & & 3.2 & 1.1 & 13.3 & 1.6 \\
\hline 3,7-dimethylocta-1,7-dien-3,6-diol & 72 & $a$ & 2121 & 58.7 & 12.9 & 64.4 & 7.2 & 55.1 & 25.0 & 3.9 & 1.1 & 12.3 & 6.0 & 14.3 & 3.9 \\
\hline citronellol hydrate & 73 & $a$ & 2196 & - & & 1.0 & 0.2 & 3.1 & 1.5 & - & & 0.7 & 0.4 & 2.4 & 1.0 \\
\hline 8-hydroxy-6,7-dihydro-linalool & 74 & $a$ & 2197 & 0.7 & 0.8 & 1.1 & 0.6 & 1.0 & 0.7 & 0.6 & 0.5 & 1.9 & 0.9 & 1.2 & 0.7 \\
\hline (E)-8-hydroxy-linalool & 75 & $a$ & 2265 & $?$ & & $?$ & & $\operatorname{tr}$ & & $?$ & & $?$ & & 3.4 & 2.5 \\
\hline (Z)-8- hydroxy-linalool & 76 & $a$ & 2302 & 0.5 & 1.3 & 2.0 & 0.4 & 2.0 & 2.0 & 2.0 & 1.0 & 15.8 & 4.2 & 30.0 & 3.7 \\
\hline$p$-1-menthen-7,8-diol & 77 & $a$ & 2517 & $\operatorname{tr}$ & & 1.4 & 0.6 & $\operatorname{tr}$ & & - & & - & & - & \\
\hline total & & & & 423.4 & & 575.2 & & 652.5 & & 87.3 & & 302.4 & & 384.5 & \\
\hline \multicolumn{16}{|l|}{$\mathrm{C}_{13}$-norisoprenoids (13) } \\
\hline vitispirane I & 78 & $a$ & 1524 & - & & 1.4 & 0.7 & 4.0 & 0.2 & - & & 2.1 & 0.5 & 9.0 & 0.5 \\
\hline vitispirane II & 79 & $a$ & 1527 & - & & 0.8 & 0.3 & 2.5 & 0.4 & - & & 1.8 & 1.1 & 7.3 & 0.9 \\
\hline 1,1,6-trimethyl-1,2-dihydronaphtalene & 80 & $b, c$ & 1741 & $\operatorname{tr}$ & & $\operatorname{tr}$ & & 0.8 & 0.2 & - & & - & & 0.6 & 0.3 \\
\hline
\end{tabular}




\begin{tabular}{|c|c|c|c|c|c|c|c|c|c|c|c|c|c|c|c|}
\hline$\beta$-damascenone & 81 & $a$ & 1816 & 4.3 & 0.7 & 1.3 & 0.3 & 0.7 & 0.1 & 5.3 & 0.8 & 3.4 & 0.2 & 1.1 & 0.3 \\
\hline 3-hydroxy- $\beta$-damascone & 82 & $a$ & 2529 & 1.0 & 0.8 & $\operatorname{tr}$ & & $\operatorname{tr}$ & & 0.9 & 0.1 & 0.7 & 0.2 & - & \\
\hline 3-hydroxy-7,8-dihydro- $\beta$-ionone & 83 & $a$ & 2533 & - & & $\operatorname{tr}$ & & - & & - & & - & & - & \\
\hline megastigm-7-ene-3,9-diol & 84 & $d$ & 2568 & - & & 4.4 & 0.9 & 4.7 & 1.4 & - & & 4.8 & 0.5 & 10.4 & 3.1 \\
\hline 3-oxo- $\alpha$-ionol & 85 & $a$ & 2628 & 4.4 & 2.1 & 7.6 & 1.5 & 7.2 & 3.7 & 3.0 & 1.8 & 7.0 & 0.7 & 10.6 & 2.5 \\
\hline 3-hydroxy-7,8-dihydro- $\beta$-ionol & 86 & $a$ & 2654 & 0.3 & 0.2 & 0.6 & 0.3 & - & & - & & 0.8 & 0.5 & $\operatorname{tr}$ & \\
\hline 3-oxo-7,8-dihydro- $\alpha$-ionol & 87 & $a$ & 2702 & 0.7 & 0.5 & 0.5 & 0.0 & 1.9 & 1.4 & $\operatorname{tr}$ & & 0.9 & 0.3 & 0.6 & 0.5 \\
\hline 3-hydroxy-5,6-epoxy- $\beta$-ionone & 88 & $a$ & 2721 & 0.7 & 0.4 & - & & $\operatorname{tr}$ & & - & & $\operatorname{tr}$ & & $\operatorname{tr}$ & \\
\hline 3-hydroxy-7,8-dehydro- $\beta$-ionol & 89 & $a$ & 2742 & - & & $\operatorname{tr}$ & & - & & - & & 0.7 & 0.1 & 0.8 & 0.2 \\
\hline vomifoliol & 90 & $a$ & 3139 & 2.0 & 1.1 & 2.4 & 0.3 & 2.4 & 1.0 & - & & $\operatorname{tr}$ & & 0.6 & 0.2 \\
\hline total & & & & 13.4 & & 19.0 & & 24.2 & & 9.2 & & 22.2 & & 41.0 & \\
\hline \multicolumn{16}{|l|}{ Volatile phenols (13) } \\
\hline methyl salicylate & 91 & $a$ & 1770 & $\operatorname{tr}$ & & $\operatorname{tr}$ & & $\operatorname{tr}$ & & $\operatorname{tr}$ & & $\operatorname{tr}$ & & $\operatorname{tr}$ & \\
\hline guaiacol & 92 & $a$ & 1852 & $\operatorname{tr}$ & & 1.2 & 1.5 & 2.8 & 2.4 & $\operatorname{tr}$ & & 2.7 & 2.0 & 3.3 & 0.4 \\
\hline phenol & 93 & $a$ & 2006 & 1.1 & 0.3 & 1.6 & 0.5 & 1.4 & 1.4 & 1.2 & 0.4 & 1.1 & 0.2 & 2.2 & 1.2 \\
\hline 4-ethylphenol & 94 & $a$ & 2172 & 1.5 & 0.6 & 0.5 & 0.3 & 1.5 & 1.6 & 1.4 & 0.1 & 1.2 & 0.5 & 0.8 & 0.2 \\
\hline 4-vinylguaiacol & 95 & $a$ & 2192 & 89.3 & 12.0 & 24.5 & 1.3 & 21.1 & 9.3 & 192.7 & 31.7 & 62.9 & 12.9 & 49.4 & 13.0 \\
\hline 4-vinylphenol & 96 & $a$ & 2409 & 50.3 & 7.4 & $\operatorname{tr}$ & & ? & & 144.9 & 31.4 & 20.9 & 5.9 & $?$ & \\
\hline vanillin & 97 & $a$ & 2560 & - & & - & & 2.9 & 0.7 & - & & $\operatorname{tr}$ & & 5.6 & 0.9 \\
\hline methyl vanillate & 98 & $a$ & 2601 & $\operatorname{tr}$ & & $\operatorname{tr}$ & & $\operatorname{tr}$ & & 10.7 & 1.5 & 7.9 & 1.6 & 7.0 & 1.7 \\
\hline acetovanillone & 99 & $a$ & 2635 & 8.9 & 2.3 & 10.8 & 1.7 & 14.4 & 7.5 & 9.8 & 4.2 & 11.6 & 0.7 & 11.4 & 2.9 \\
\hline 3,4-dimethoxyphenol & 100 & $a$ & 2759 & - & & - & & $\operatorname{tr}$ & & $\operatorname{tr}$ & & 0.7 & 0.1 & 1.1 & 0.4 \\
\hline 2-(4'-guaiacyl)-ethanol & 101 & $a$ & 2844 & 6.1 & 1.9 & 6.7 & 2.5 & 8.2 & 6.1 & 0.8 & 0.3 & 2.5 & 0.2 & 2.1 & 1.0 \\
\hline 3,4,5-trimethoxybenzyl alcohol & 102 & $a$ & 2879 & 4.3 & 0.5 & 5.1 & 1.8 & 6.4 & 3.0 & 4.3 & 2.2 & 8.0 & 0.8 & 9.8 & 2.2 \\
\hline 3,4,5-trimethoxyphenol & 103 & $a$ & 3060 & 1.2 & 0.3 & 2.6 & 1.2 & 1.6 & 1.7 & $\operatorname{tr}$ & & 1.9 & 0.8 & 2.2 & 0.6 \\
\hline total & & & & 162.7 & & 53.0 & & 60.3 & & 365.8 & & 121.4 & & 94.9 & \\
\hline \multicolumn{16}{|l|}{$\begin{array}{l}\text { Volatile fatty acids - lipid } \\
\text { metabolism ( } 8 \text { ) }\end{array}$} \\
\hline acetic acid & 104 & $a$ & 1453 & 16.0 & 7.6 & 9.4 & 4.2 & 19.3 & 13.8 & 16.1 & 4.9 & 16.1 & 6.1 & 18.2 & 7.5 \\
\hline butanoic acid & 105 & $a$ & 1626 & 133.1 & 71.0 & 125.3 & 20.1 & 138.3 & 97.4 & 156.7 & 42.5 & 139.2 & 33.5 & 131.5 & 13.5 \\
\hline hexanoic acid & 106 & $a$ & 1841 & 2995.1 & 561.1 & 3045.0 & 497.4 & 3716.8 & 1630.1 & 3461.6 & 972.9 & 3643.4 & 326.3 & 3331.7 & 179.4 \\
\hline (E)-2-hexenoic acid & 107 & $a$ & 1964 & 21.2 & 2.7 & 23.0 & 5.9 & 24.0 & 8.6 & 14.9 & 3.2 & 16.9 & 3.4 & 10.4 & 2.0 \\
\hline octanoic acid & 108 & $a$ & 2057 & 3501.4 & 259.4 & 3565.4 & 264.1 & 2902.4 & 298.9 & 3235.2 & 347.8 & 3419.2 & 218.5 & 2844.8 & 148.6 \\
\hline decanoic acid & 109 & $a$ & 2269 & 1451.7 & 218.8 & 1418.4 & 111.3 & 1080.9 & 339.8 & 1739.8 & 84.9 & 1542.7 & 311.6 & 1222.2 & 71.9 \\
\hline dodecanoic acid & 110 & $a$ & 2481 & 17.6 & 2.8 & 12.6 & 3.9 & 4.8 & 3.5 & 27.4 & 5.2 & 13.7 & 4.9 & 4.1 & 1.5 \\
\hline hexadecanoic acid & 111 & $a$ & 2903 & $\operatorname{tr}$ & & $\operatorname{tr}$ & & - & & 1.9 & 2.2 & $\operatorname{tr}$ & & $\operatorname{tr}$ & \\
\hline total & & & & 8136.1 & & 8199.1 & & 7886.5 & & 8653.6 & & 8791.2 & & 7562.9 & \\
\hline \multicolumn{16}{|l|}{$\begin{array}{l}\text { Volatile fatty acids - nitrogen } \\
\text { metabolism (3) }\end{array}$} \\
\hline 2-methylpropanoic acid & 112 & $a$ & 1567 & 59.2 & 27.7 & 52.1 & 7.6 & 54.4 & 39.0 & 71.4 & 20.8 & 56.7 & 10.8 & 52.1 & 6.7 \\
\hline $\begin{array}{l}\text { 3-methylbutyric acid } \\
+2 \text {-methylbutyric acid }\end{array}$ & $\begin{array}{l}113 \\
114\end{array}$ & $\begin{array}{l}a \\
a\end{array}$ & 1667 & 241.2 & 115.0 & 206.9 & 16.7 & 234.3 & 138.7 & 361.1 & 88.6 & 311.7 & 50.4 & 269.7 & 24.5 \\
\hline total & & & & 300.4 & & 259.0 & & 288.7 & & 432.5 & & 368.4 & & 321.8 & \\
\hline \multicolumn{16}{|l|}{ Carbonyl compounds (4) } \\
\hline 2-nonanone & 115 & $a$ & 1386 & 1.3 & 0.2 & 1.5 & 0.1 & 1.0 & 0.4 & 2.4 & 0.2 & 2.7 & 0.5 & 2.7 & 0.2 \\
\hline 2-furaldehyde & 116 & $a$ & 1460 & - & & 0.3 & 0.3 & 5.2 & 12.2 & - & & 0.6 & 0.1 & 6.8 & 0.9 \\
\hline benzaldehyde & 117 & $a$ & 1517 & 7.4 & 1.9 & 7.1 & 0.7 & 8.9 & 5.8 & 8.3 & 2.0 & 7.9 & 0.8 & 7.4 & 0.1 \\
\hline 4-ethylbenzaldehyde & 118 & $a$ & 1703 & 25.5 & 4.6 & 25.7 & 8.7 & 28.7 & 17.7 & 27.6 & 8.1 & 27.2 & 5.1 & 22.4 & 1.9 \\
\hline total & & & & 34.2 & & 34.6 & & 43.8 & & 38.3 & & 38.4 & & 39.3 & \\
\hline \multicolumn{16}{|l|}{ Other (2) } \\
\hline pantolactone & 119 & $a$ & 2026 & 3.0 & 0.8 & 6.9 & 2.0 & 10.5 & 9.5 & 2.2 & 1.1 & 4.8 & 1.2 & 7.8 & 2.4 \\
\hline $\mathrm{N}$-(2-phenylethyl)-acetamide & 120 & $a$ & 2575 & 91.4 & 24.1 & 89.5 & 6.5 & 92.4 & 46.3 & 46.7 & 13.3 & 53.5 & 8.2 & 41.9 & 3.3 \\
\hline total & & & & 94.4 & & 96.4 & & 102.9 & & 48.9 & & 58.3 & & 49.7 & \\
\hline
\end{tabular}




\begin{tabular}{|c|c|c|c|c|c|c|}
\hline TOTAL & 102953.3 & 99468.8 & 134450.4 & 111889.6 & 108817.4 & 115556.6 \\
\hline TOTAL $^{* *}$ & 16221.9 & 21166.1 & 38585.8 & 16893.2 & 21285.3 & 33419.6 \\
\hline
\end{tabular}

roi, reliability of identification

$\mathrm{RI}$, linear retention index on column CP-Wax $52 \mathrm{CB}$

$a$, identified by comparing retention time and mass spectra with those of a pure standard

$b$, identified by comparing retention index with published data

$c$, identified by comparing mass spectra with published data

$d$, tentative identification: molecular weight $=212 \mathrm{~g} / \mathrm{mol} ; \mathrm{m} / \mathrm{z}(\%)=43$ (100.0), 41 (42.8), 39 (30.9), 29 (25.2), $79(20.4), 55$

(18.2), 97 (18.0), 120 (16.6), 94 (15.4), 77 (14.4); other characteristic ions, $\mathrm{m} / \mathrm{z}(\%)=212$ (int, $\mathrm{M}^{+}$), 179 (int, $\left.\mathrm{M}^{+}-\mathrm{H}_{2} \mathrm{O}_{-} \mathrm{CH}_{3}\right)$, 161 (int, $\mathrm{M}^{+}-2 \mathrm{H}_{2} \mathrm{O}-\mathrm{CH}_{3}$ )

*, levels were determined as 4-nonanol equivalents

**, without 2-methyl-1-butanol, 3-methyl-1-butanol and 2-phenylethanol

?, quantification not possible

- , not detected

tr, traces 
Table 3. Behavior during maturation, of volatile compounds found in Loureiro and Alvarinho wines

\begin{tabular}{|c|c|c|c|c|c|}
\hline \multirow[b]{2}{*}{ Behavior } & \multirow[b]{2}{*}{ Compound } & \multicolumn{2}{|l|}{ Loureiro } & \multicolumn{2}{|c|}{ Alvarinho } \\
\hline & & $\begin{array}{l}\text { Regression } \\
\text { equation }\end{array}$ & $\mathbf{R}^{2}$ & $\begin{array}{l}\text { Regression } \\
\text { equation }\end{array}$ & $\mathbf{R}^{2}$ \\
\hline \multirow{5}{*}{ Increase } & ethyl 2-methylbutyrate & $y=-a+b x$ & 0.988 & $y=-a+b x$ & 0.991 \\
\hline & ethyl 3-methylbutyrate & $y=a+b x+c x^{2}$ & 0.997 & $y=a+b x+c x^{2}$ & 0.999 \\
\hline & diethyl succinate & $y=a+b x+c x^{2}$ & 0.979 & $y=a+b x+c x^{2}$ & 0.998 \\
\hline & neroloxide & $y=a+b x$ & 0.975 & $y=a+b x+c x^{2}$ & 0.998 \\
\hline & guaiacol & $y=a+b x$ & 0.791 & $y=-a+b x-c x^{2}$ & 0.933 \\
\hline \multirow{14}{*}{ Decrease } & (Z)-3-hexen-1-ol & (lack of correlation) & 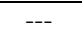 & $y=a-b x+c x^{2}$ & 0.822 \\
\hline & 3-methylthio-1-propanol & (lack of correlation) & --- & $y=a-b x$ & 0.912 \\
\hline & ethyl butyrate & (lack of correlation) & --- & $y=a-b x$ & 0.677 \\
\hline & ethyl hexanoate & $y=a-b x-c x^{2}$ & 0.922 & $y=a-b x+c x^{2}$ & 0.541 \\
\hline & ethyl decanoate & $y=a-b x+c x^{2}$ & 0.916 & (maximum at $W_{2}$ ) & --- \\
\hline & 3-methylbutyl acetate & $y=a-b x+c x^{2}$ & 0.998 & $y=a-b x+c x^{2}$ & 0.997 \\
\hline & hexyl acetate & $y=a-b x+c x^{2}$ & 1.000 & $y=a-b x$ & 0.997 \\
\hline & 2-phenylethyl acetate & $y=a-b x+c x^{2}$ & 0.999 & $y=a-b x$ & 1.000 \\
\hline & linalool & $y=a-b x+c x^{2}$ & 0.998 & (maximum at $W_{2}$ ) & --- \\
\hline & citronellol & $y=a-b x+c x^{2}$ & 0.988 & $y=a-b x$ & 0.987 \\
\hline & $\beta$-damascenone & $y=a-b x+c x^{2}$ & 0.992 & $y=a-b x+c x^{2}$ & 0.991 \\
\hline & 4-vinylguaiacol & $y=a-b x+c x^{2}$ & 0.992 & $y=a-b x+c x^{2}$ & 0.989 \\
\hline & decanoic acid & $y=a+b x-c x^{2}$ & 0.816 & $y=a-b x$ & 0.920 \\
\hline & $\begin{array}{l}\text { 3-methylbutanoic acid } \\
+3 \text {-methylbutanoic acid }\end{array}$ & (lack of correlation) & --- & $y=a-b x+c x^{2}$ & 0.779 \\
\hline \multirow{6}{*}{$\begin{array}{l}\text { Maximum } \\
\text { at } W_{2}\end{array}$} & ethyl octanoate & $y=a+b x-c x^{2}$ & 0.671 & (lack of correlation) & --- \\
\hline & ethyl decanoate & (decreasing behaviour) & --- & $y=a+b x-c x^{2}$ & 0.723 \\
\hline & linalool & (decreasing behaviour) & --- & $y=a+b x-c x^{2}$ & 0.998 \\
\hline & Ho-trienol & $y=a+b x-c x^{2}$ & 0.905 & $y=a+b x-c x^{2}$ & 0.959 \\
\hline & $\alpha$-terpineol & $y=a+b x-c x^{2}$ & 0.987 & $y=a+b x-c x^{2}$ & 0.993 \\
\hline & octanoic acid & $y=a+b x-c x^{2}$ & 0.916 & $y=a+b x-c x^{2}$ & 0.893 \\
\hline
\end{tabular}


Table 4. Sensory characterisation of Loureiro and Alvarinho wines with 8 months $\left(\mathrm{W}_{2}\right)$ and 20 months $\left(\mathrm{W}_{3}\right)$, represented by the median of each attribute and the average of the final classification (attributes ranging from 0 to 5 in order of increasing intensity)

\begin{tabular}{|c|c|c|c|c|c|}
\hline \multirow{2}{*}{\multicolumn{2}{|c|}{ Attribute }} & \multicolumn{2}{|c|}{ Loureiro } & \multicolumn{2}{|c|}{ Alvarinho } \\
\hline & & $\mathbf{W}_{2}$ & $\mathbf{W}_{3}$ & $\mathbf{W}_{2}$ & $\mathbf{W}_{3}$ \\
\hline $\begin{array}{l}\text { Visual } \\
\text { Assessment }\end{array}$ & $\begin{array}{l}\text { clarity } \\
\text { colour } \\
\text { colour quality }\end{array}$ & $\begin{array}{c}\text { limpid } \\
\text { pale citrus } \\
2\end{array}$ & $\begin{array}{c}\text { limpid } \\
\text { citrus } \\
3\end{array}$ & $\begin{array}{c}\text { limpid } \\
\text { open straw } \\
3\end{array}$ & $\begin{array}{c}\text { limpid } \\
\text { open straw } \\
3\end{array}$ \\
\hline $\begin{array}{l}\text { Olfactory } \\
\text { Assessment }\end{array}$ & $\begin{array}{l}\text { intensity } \\
\text { floral } \\
\text { citrus fruit } \\
\text { tree fruit } \\
\text { tropical fruit } \\
\text { dried fruit } \\
\text { vegetal } \\
\text { overall sensation }\end{array}$ & $\begin{array}{l}3 \\
2 \\
3 \\
1 \\
1 \\
0 \\
0 \\
3\end{array}$ & $\begin{array}{l}3 \\
2 \\
2 \\
2 \\
1.5 \\
0 \\
1 \\
3\end{array}$ & $\begin{array}{l}4 \\
2 \\
1.5 \\
3 \\
3 \\
0.5 \\
0 \\
4\end{array}$ & $\begin{array}{l}3.5 \\
1.5 \\
1 \\
3 \\
2 \\
1 \\
1 \\
3\end{array}$ \\
\hline $\begin{array}{l}\text { Gustative } \\
\text { Assessment }\end{array}$ & $\begin{array}{l}\text { sweetness } \\
\text { acidity } \\
\text { heat } \\
\text { bitterness } \\
\text { structure } \\
\text { balance } \\
\text { persistence } \\
\text { overall sensation }\end{array}$ & $\begin{array}{l}1 \\
3 \\
2 \\
1 \\
3 \\
2.5 \\
3 \\
3\end{array}$ & $\begin{array}{l}1 \\
3.5 \\
2 \\
2 \\
3 \\
3 \\
3 \\
3\end{array}$ & $\begin{array}{l}2 \\
2 \\
4 \\
0.5 \\
3 \\
4 \\
4 \\
4\end{array}$ & $\begin{array}{l}2 \\
2.5 \\
3 \\
1 \\
3 \\
3 \\
3 \\
3.5\end{array}$ \\
\hline $\begin{array}{l}\text { Final } \\
\text { Classification }\end{array}$ & $\begin{array}{l}\text { (median) } \\
\text { (mean) }\end{array}$ & 13.5 & 12.9 & 15.5 & 14.9 \\
\hline
\end{tabular}




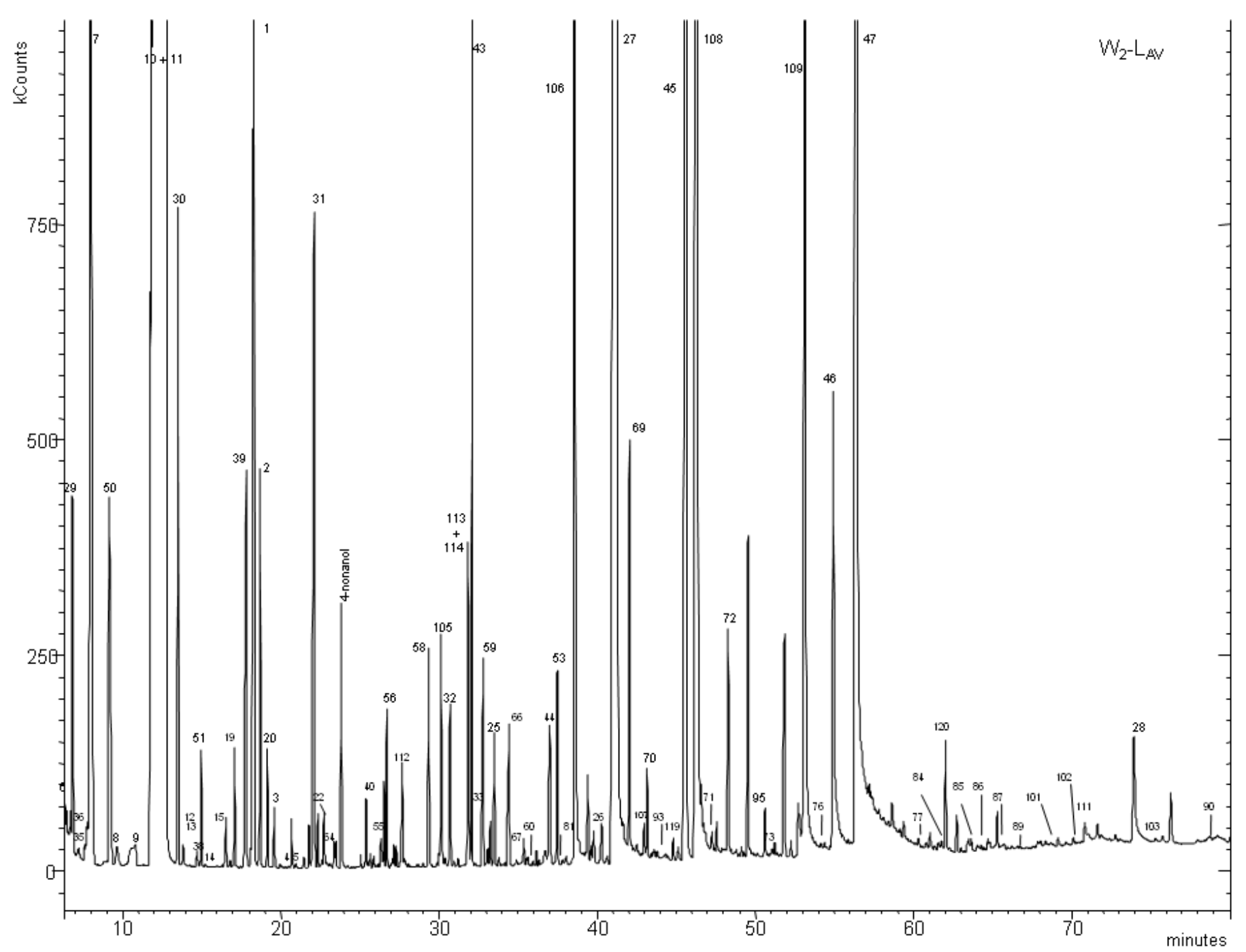

Figure 1. Representative section of a GC-MS chromatogram respecting $\mathrm{W}_{2}$ Loureiro wine (peak identification may be assessed on table 2). 

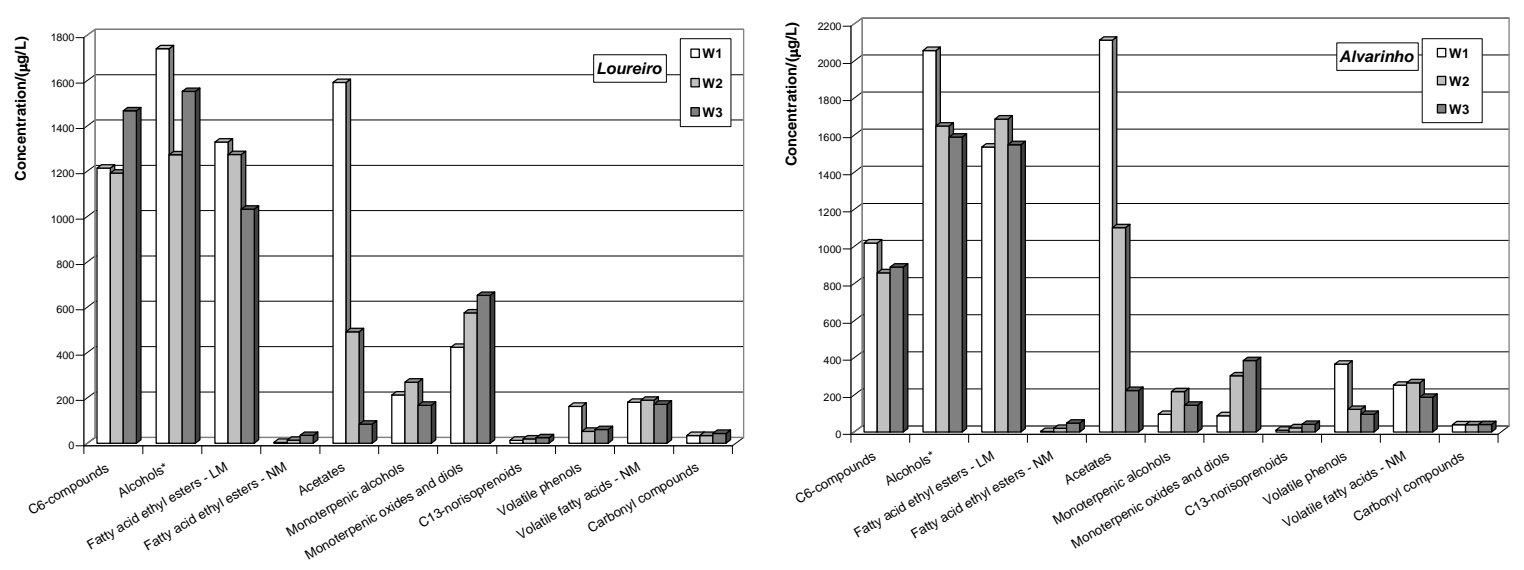

Figure 2. Evolution of each group of volatile compounds in the Loureiro and Alvarinho wines, after alcoholic fermentation $\left(\mathrm{W}_{1}\right)$ and with 8 months $\left(\mathrm{W}_{2}\right)$ and 20 months $\left(\mathrm{W}_{3}\right){ }^{*}$ without 2-methyl-1-butanol, 3-methyl-1-butanol and 2-phenylethanol; LM - lipid metabolism, NM - nitrogen metabolism). 

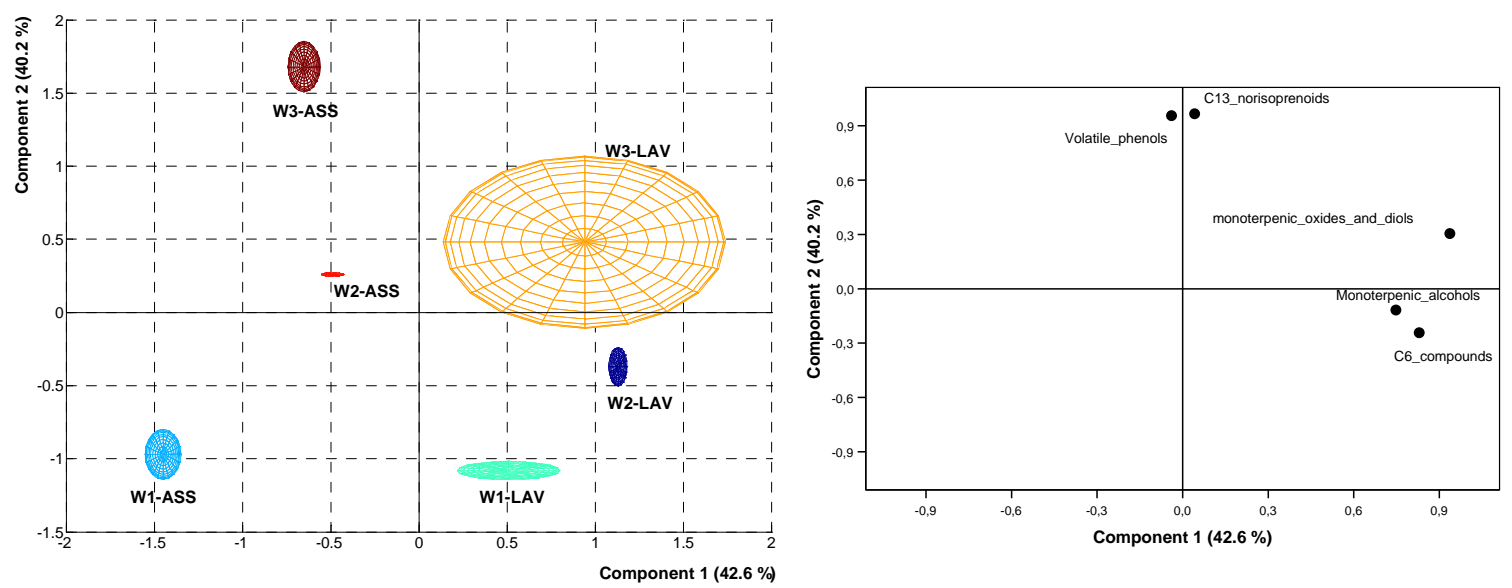

Figure 3. Graphic representation of the two principal components for the volatile varietal compounds (total levels by groups) of $\mathrm{W}_{1}, \mathrm{~W}_{2}$ and $\mathrm{W}_{3}$ wines of Alvarinho and Loureiro varieties. The ellipsoids represent the $95 \%$ confidence level. 

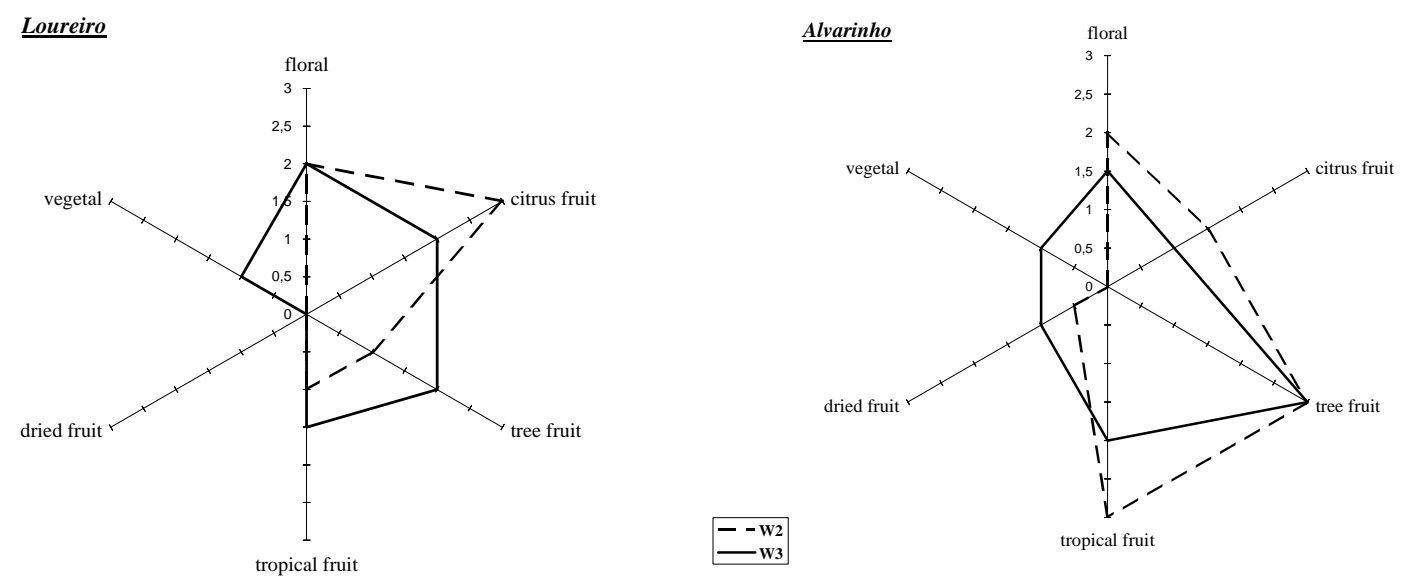

Figure 4. Aromatic descriptor intensity (median) for Loureiro and Alvarinho wines at the $\mathrm{W}_{2}$ and $\mathrm{W}_{3}$ stages. 